\title{
Taxonomy of the Cixiidae (Hemiptera, Fulgoromorpha) from the Madeira archipelago
}

\author{
Énio FREITAS ${ }^{1}$ \& Dora AGUÍN-POMBO ${ }^{2, *}$ \\ ${ }^{1,2}$ University of Madeira, 9000-390 Funchal, Madeira, Portugal. \\ ${ }^{2}$ Centro de Investigação em Biodiversidade e Recursos Genéticos (CIBIO), Vairão, Portugal. \\ ${ }^{*}$ Correspondig author: aguin@staff.uma.pt \\ ${ }^{1}$ enio.freitas@staff.uma.pt \\ ${ }^{1}$ urn:Isid:zoobank.org:author:7D9D7B00-F712-456C-B962-9CA22F93154B \\ ${ }^{2}$ urn:lsid:zoobank.org:author:62471063-562B-407A-8781-8F6AB0635C14
}

\begin{abstract}
Ninety percent of the Cixiidae of the Macaronesian archipelagos are endemic. Each archipelago has its own endemics reaching a total of 31 taxa. The Madeira archipelago comprises five species: Cixius madeirensis China, 1938, C. verticalis Noualhier, 1897, C. chaoensis China, 1938, Hyalesthes madeires Remane \& Hoch, 1986 and H. portonoves Remane \& Hoch, 1986. Good knowledge concerning taxonomy, habitat information and distribution are essential for the conservation of the biodiversity of this rich archipelago. However, due to intraspecific variation and incomplete descriptions, misidentifications of Madeira cixiids have been common. In this work, the taxonomy of this family is reviewed and ecological data based on material collected over more than forty years are presented. A new species, Cixius wollastoni sp. nov., is described. A new combination, Tachycixius chaoensis (China, 1938) comb. nov., is proposed, and a new record, Pentastiridius leporinus (Linnaeus, 1761), is reported. Lectotypes are designated for Tachycixius chaoensis and $C$. verticalis. The genital structures of the latter species are depicted for the first time. All species are diagnosed, described, photographed and illustrated, and an identification key for the family is provided. Thanks to this new information, Madeira together with Tenerife are the two Macaronesian islands with the highest number of endemic species of cixids.
\end{abstract}

Keywords. Auchenorrhyncha, endemic, Macaronesia, new species, planthopper.

Freitas É. \& Aguín-Pombo D. 2021. Taxonomy of the Cixiidae (Hemiptera, Fulgoromorpha) from the Madeira archipelago. European Journal of Taxonomy 744: 1-37. https://doi.org/10.5852/ejt.2021.744.1295

\section{Introduction}

Macaronesia belongs to the biodiversity hotspot of the Mediterranean Basin (Médail \& Quézel 1999; Myers et al. 2000). It is a distinctive biogeographic unit that includes the archipelagoes of Madeira, the Azores, Cape Verde, Selvagens and the Canary Islands. These archipelagos have in common a Tertiary relict flora with survivors of the plant communities distributed throughout southern Europe and North Africa some 15-40 Ma ago (review in Vanderpoorter et al. 2007). 
Planthoppers of the Cixiidae Spinola, 1839 family are successful colonizers of remote archipelagos where they often give rise to many endemic species, e.g., Hawaii (Asche 1997), Mascarenes (Attié et al. 2002), Marquesas Islands (Adamson 1939), Seychelles (Holzinger et al. 2008) and Fiji (Wilson 2009). Likewise, some Cixiidae lineages have greatly differentiated in Macaronesia, resulting in 31 endemic taxa. Of these, 15 are present in the Canary Islands (Horváth 1909; Lindberg 1954, 1960; Hoch \& Remane 1985; Remane \& Hoch 1988; Hoch \& Asche 1993), 11 in the Azores (Lindberg 1954; Remane \& Asche 1979; Hoch 1991) and 5 in the Madeira archipelago (Noualhier 1897; China 1938; Hoch \& Remane 1985; Remane \& Hoch 1986). One-third of these species (10 spp.) are troglobites, i.e., obligate cavernicolous who have evolutionarily adapted to life in caves (Remane \& Hoch 1988; Hoch 1991; Hoch \& Asche 1993). Endemic taxa are confined mainly to a single island, sometimes to a single lava tube (Hoch 1991; Hoch \& Asche 1993). The Madeira archipelago has six species, four restricted to the Island of Madeira (C. madeirensis China, 1938, C. verticalis Noualhier, 1897, Hyalesthes madeires Remane \& Hoch, 1986 and H. portonoves Remane \& Hoch, 1986) and one, Cixius chaoensis China, 1938, is circumscribed to the islet of Ilhéu Chão. For the remaining 4 islands and 8 islets, there is no record of this family (Aguín-Pombo \& Freitas 2008) and the same applies to the small archipelago of the Selvagens Islands (two small islands and several islets, $\sim 3 \mathrm{~km}^{2}$ ), located $\sim 255 \mathrm{~km}$ south of the island of Madeira.

The Cixiidae of Madeira have been the subject of six taxonomic publications focused primarily on species descriptions and/or species records (Noualhier 1897; China 1938; Lindberg 1941, 1961; Hoch \& Remane 1985; Remane \& Hoch 1986). These works were based primarily on the material sampled by Wollaston before 1958 (China 1938), by Lindberg (year 1957) or by him and his assistant Panelius (year 1959) and finally by Remane (years 1957, 1967, 1970, 1977). A few additional specimens were collected by Fauvel (year 1896), Lundbland (year 1935) and Frey (year 1938) during their expeditions to Madeira. Detailed studies of the family are provided in the monograph of the genus Hyalesthes Signoret, 1865 by Hoch \& Remane (1985). These authors described a new unknown species, H. portonoves, and conducted a phylogenetic analysis of this genus. They placed the Hyalesthes species of Madeira together with part of the species of the Canary Islands into the group of H. angustulus Horváth, 1909.

Misidentifications, mainly due to incomplete descriptions of species, have been common in the studies of the Cixiidae of Madeira: Lindberg (1941) believed that C. verticalis occurs both in Madeira and the Azores. He also identified Hyalesthes from Madeira as H. angustulus and later as H. flavipennis Horváth, 1909 (Lindberg 1961), both present in the Canary Islands. Hoch \& Remane (1985), after examining the type material, concluded that the Hyalesthes of Madeira were two different species, and described them as $H$. portonoves and $H$. madeires. The main reason for the misidentifications of cixiids was the large intraspecific variation in body size and genital structures, also present in the Azores and Canary Islands species (Remane \& Asche 1979; Hoch \& Remane 1985). The cause of this variation is unknown, but it is believed that in Cixius, in part, it is driven by climatic influences (Remane \& Asche 1979; Hoch \& Remane 1985).

Published studies of the Cixiidae family of the Madeira archipelago are still fragmentary. For some species, the descriptions are still incomplete and/or based on a small number of specimens. Data on the ecology and distribution is scarce and based on fieldwork dating back 40 years. Accurate identification and good data on habitat requirements are essential for the conservation of the species of this rich archipelago. Especially notable is the case of Cixius azopifajo Remane \& Asche, 1979, present in two lava tubes of Faial (Azores). It is ranked among the 100 terrestrial species of Macaronesia (plants, animals, and fungi) that require immediate measures for its conservation (Martín et al. 2008). In contrast to this, the conservation status of the remaining species in the family is unknown. This paper gives a complete account of the taxonomy of Madeira Cixiidae, based on museum specimens and field studies. 
This study shows that there are seven species of cixiids in the Madeira archipelago. All species, except one, are endemic to Madeira Island and inhabit areas with the native flora. Madeira, together with Tenerife, are the two Macaronesian islands with the largest number of endemic species.

\section{Study areas}

This study took place in the Madeira archipelago, located in the North Atlantic, between a latitude $32^{\circ} 20^{\prime}-33^{\circ} 10^{\prime} \mathrm{N}$ and longitude of $16^{\circ} 10^{\prime}-17^{\circ} 20^{\prime} \mathrm{W}$, about $650 \mathrm{~km}$ from the northwest coast of Africa, the closest continental point (Fig. 1). The Madeira archipelago is of volcanic origin and comprises 10 offshore rocks and 5 main islands (description in Aguín-Pombo \& Pinheiro de Carvalho 2009). The largest is Madeira Island $\left(741 \mathrm{~km}^{2}\right)$, about $20 \mathrm{~km}$ offshore are the Desertas Islands, and $\sim 40 \mathrm{~km}$ away

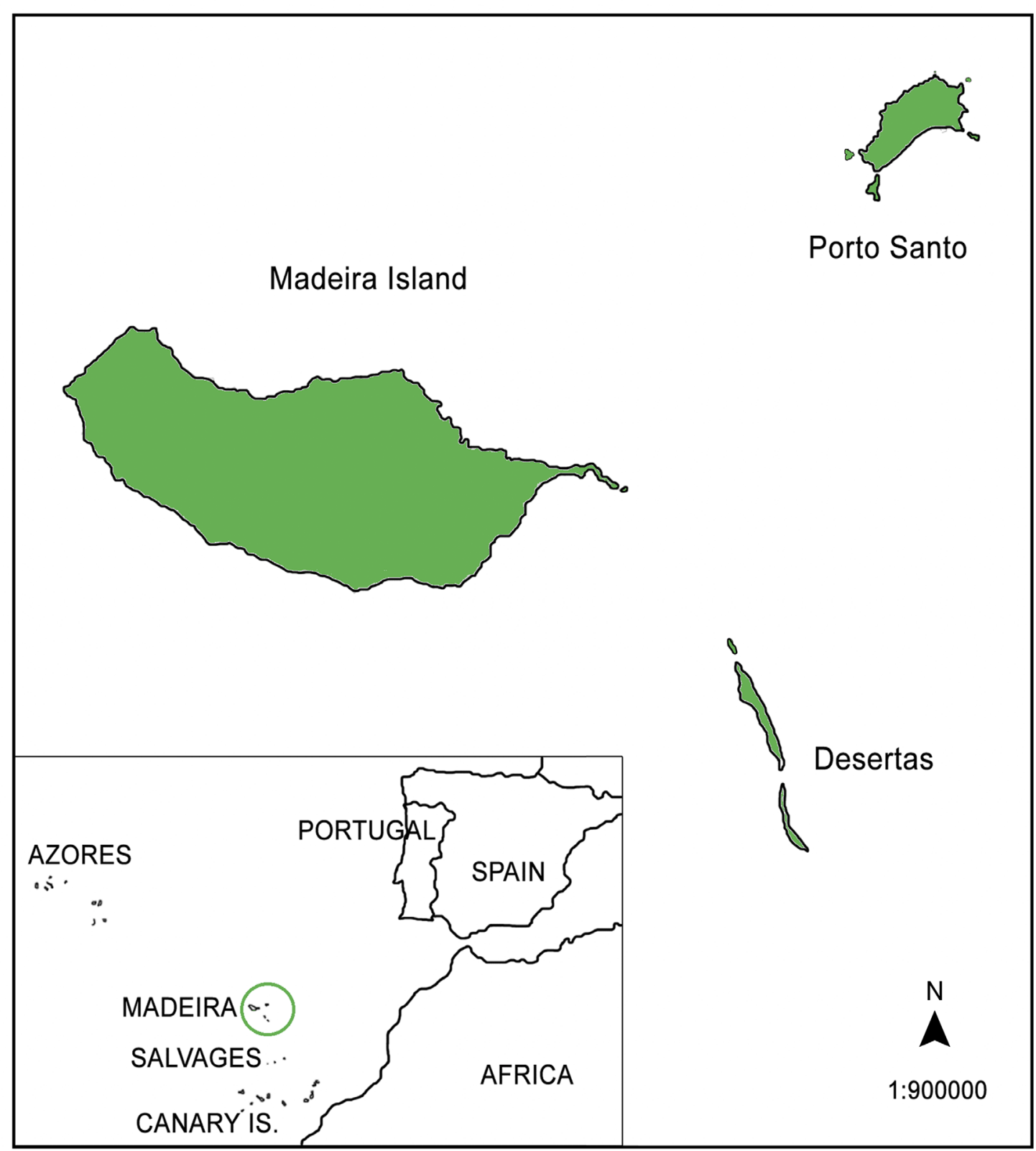

Fig. 1. Map of the Madeira archipelago. 
from these is the island of Porto Santo $\left(42 \mathrm{~km}^{2}\right.$, the highest point $\left.517 \mathrm{~m}\right)$. Madeira Island is also the highest $(1862 \mathrm{~m})$ and the steepest, with $90 \%$ of its surface being more than $500 \mathrm{~m}$ above sea level. The Desertas Islands include the islet Ilhéu Chão $\left(\sim 1 \mathrm{~km}^{2}, \sim 80 \mathrm{~m}\right.$ the highest point), Deserta Grande ( 10 $\mathrm{km}^{2}$, the highest point of $\left.479 \mathrm{~m}\right)$ and Bugio $\left(3 \mathrm{~km}^{2}\right.$, the highest point of $\left.\sim 411 \mathrm{~m}\right)$. The climate of Madeira is mild with dry and warm summers while Porto Santo is hot and dry (Cropper 2013).

The island of Madeira has the largest number of different habitat types. Around 20\% of its surface is occupied by laurel forest - Laurissilva - which is the most significant type of vegetation (Press \& Short 1994). The main tree species of this evergreen humid forest are Ocotea foetens (Aiton) Baill., Laurus novocanariensis Rivas Mart., Lousã, Fern.Prieto, E.Días, J.C.Costa \& C.Aguiar, Clethra arborea Aiton, Myrica faia Aiton, Persea indica Spreng., and Apollonias barbusana A.Braun (Neves et al. 1996). This pristine forest, recognized as a World Heritage (IUCN 1999), is very rich in endemic plants and animals, particularly insects (Borges et al. 2008). The eastern end of this island consists of a long and low peninsula known as Ponta de São Lourenço. This semi-arid area, also rich in endemic species, is the driest part of the island. Here, the vegetation is essentially xerophytic dominated by herbaceous plants, among others Hyparrhenia hirta (L.) Stapf, and halophyte shrubs of Suaeda vera Forssk. ex J.F.Gmel. (Sjögren 1972; Fontinha \& Carvalho 1995). The Desertas Islands are a Biogenetic Reserve and are included in the Natura 2000 Network. They also have endemic plants and the vegetation is mainly made up of rupicolous plants, halophytes, grasses (i.e., Holcus lanatus L.) and ferns (i.e., Pteridium aquilinum (L.) Kuhn) (Hampshire 1984; Neves et al. 1992). The island of Porto Santo suffers from desertification and severe erosion caused by intense anthropogenic use (Faust-Lichtenberger 1988). Vegetation is essentially composed of herbaceous xerophilous plants, some of which are endemic (Jardim et al. 1998). Most of the native forest species of this island have become extinct (Jardim et al. 1998; Carvalho et al. 2013) and replaced by many woody exotic plants (Søndergaard 1995).

\section{Material and methods}

\section{Fieldwork}

The specimens of this study come mainly from samples targeting the collection of cixiids, but also from regular surveys devoted to the study of insects associated with native and/or introduced plants. The specimens were collected by sweeping with a net over the vegetation on the island of Madeira and the Desertas Islands (Ilhéu Chão and Deserta Grande). No cixids were found in Porto Santo. The swept plants are approximately 90 species, including ferns, grasses, shrubs, and trees, and comprise representatives of endemic, indigenous, and introduced plants. All specimens, except the one from Corredor Verde, were stored dry or in a mixture of $70 \%$ alcohol and $2 \%$ glycerol and air-dried before being studied. All specimens were pinned and fixed on small cards and those conserved previously in alcohol were air-dried before being studied.

\section{Material studied}

The male genitalia were first boiled in a $10 \% \mathrm{KOH}$ solution, cleaned with distilled water and placed on a slide with a drop of glycerol. After the examination, all structures were glued with Dimethyl Hydantoin-Formaldehyde resin (DMHF) on small cards along with the specimens. Illustrations of the genital structures were made with a drawing camera attached to a microscope (Olympus BX50). Digital photographs of the specimens and the body measurements were made by the authors with a digital camera (Olympus DP11) coupled to a stereo microscope (Olympus SZH10) and later analyzed with the Olympus DP-soft ver. 3.0 image analysis system. For each species, 5 measurements were taken from individuals of different populations: the body length (BL), length of the mesonotum (ML), the width of the mesonotum (MW), pronotum width (PW) and right-wing length (WL) (Table 1, Fig. 2). In addition, the vertex width (VW) of the Hyalesthes spp. was measured. Pentastiridius leporinus (Linnaeus, 1761) (VW) and the lectotype of Cixius verticalis (HW - head width and VL - vertex length) were measured 


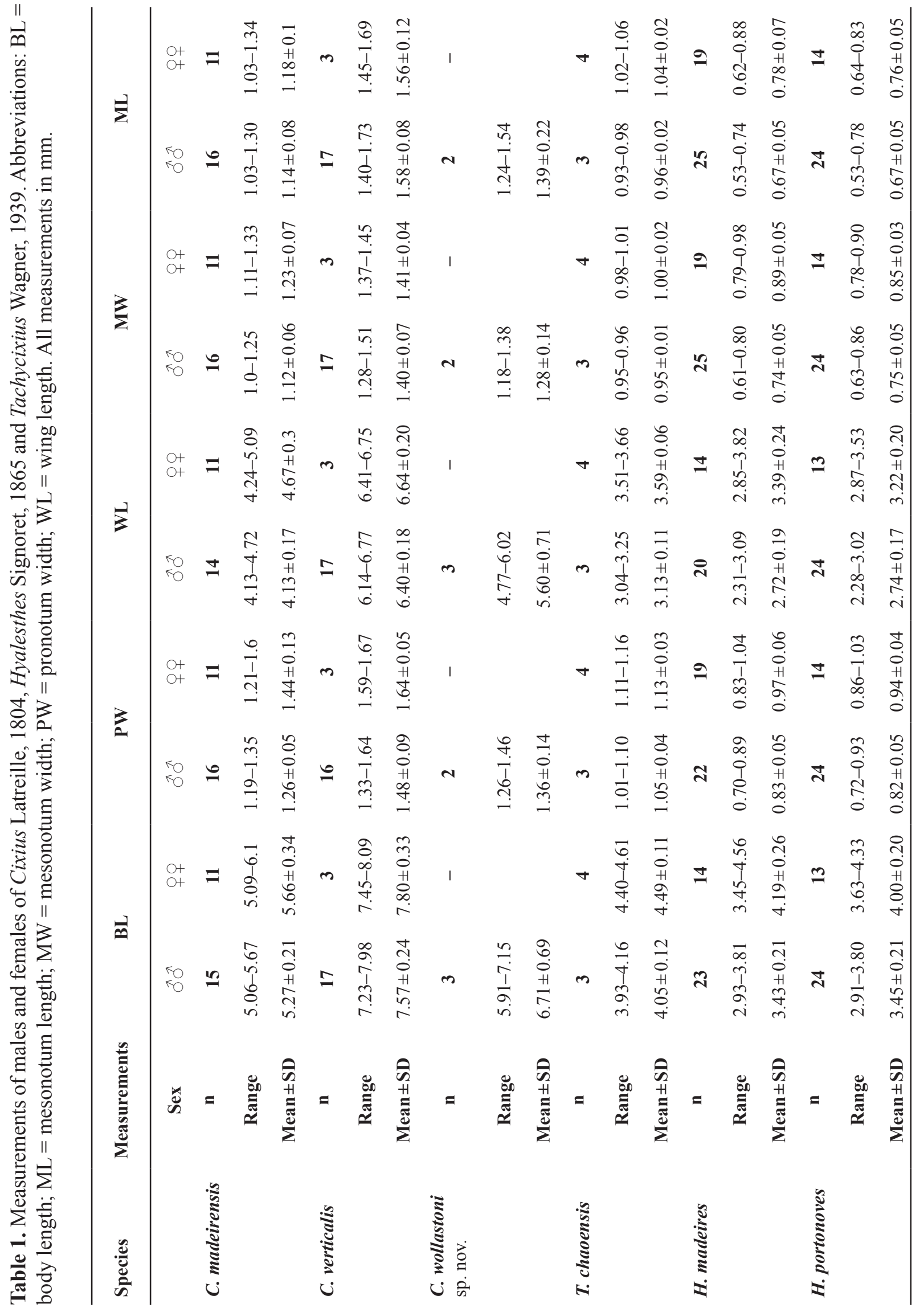




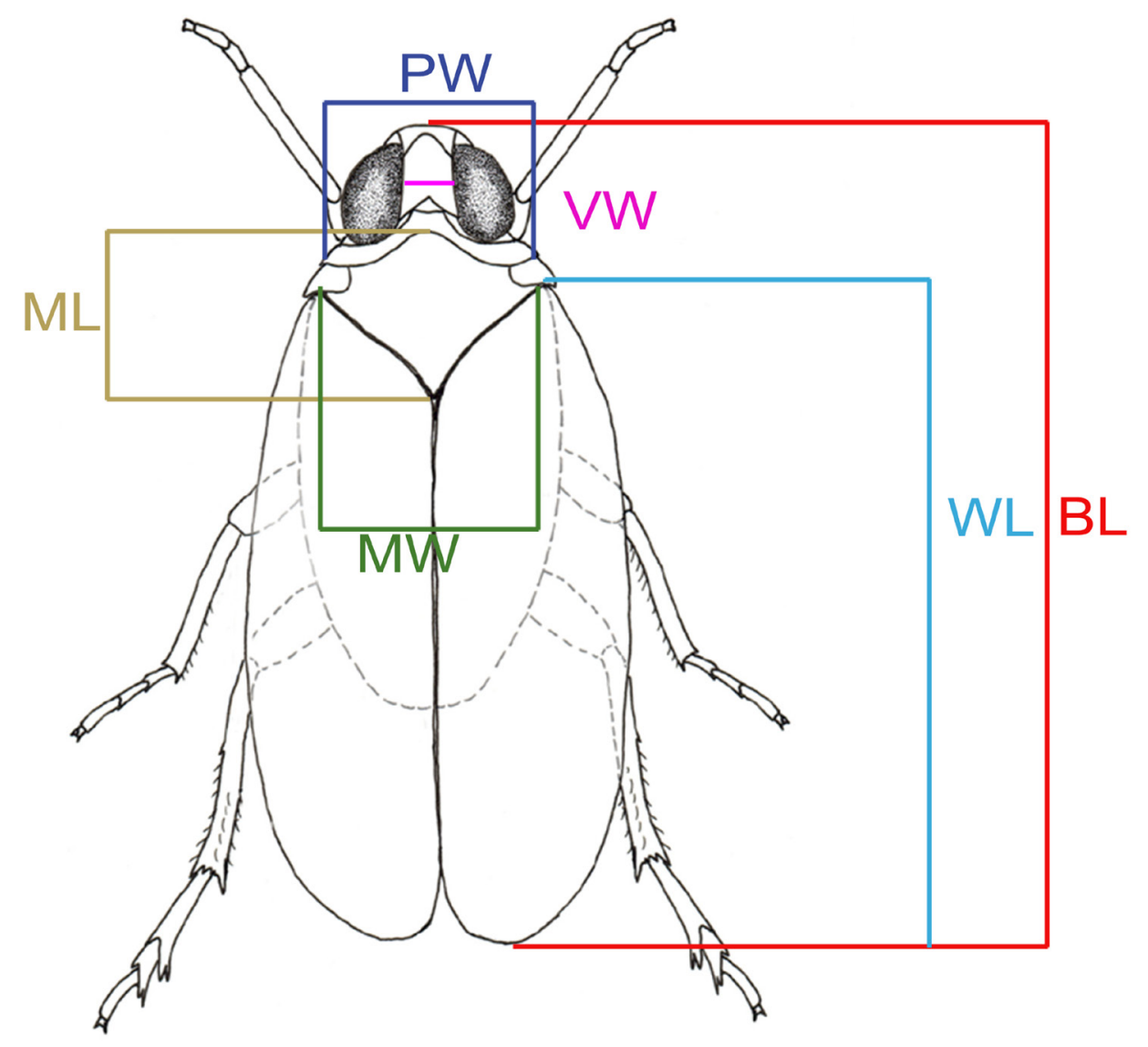

Fig. 2. Measurements of body structures. Abbreviations: $\mathrm{BL}=$ body length; $\mathrm{ML}=$ mesonotum length; $\mathrm{MW}=$ mesonotum width; $\mathrm{PW}=$ pronotum width; $\mathrm{VW}=$ width of the vertex at the anterior margin; $\mathrm{WL}=$ length of the right forewing.

with a stereo microscope with a micrometer eyepiece (Leica WILD M3B). Digital images were stacked with Combine ZP ver. 1.0 and the final plates were prepared with Adobe Photoshop CS 8.0.

The measurements of Hyalesthes spp. were statistically analyzed by one-way ANOVA ( $F$-statistic, $p<0.05$ ). All measurements were normally distributed, and their variances did not differ significantly (Levene's test, $p>0.05$ ). Likewise, PW measurements in males of $C$. madeirensis and $C$. verticalis were compared using Welch's $t$-test $(p<0.05)$. In this case, the size and variance of the samples were uneven but normally distributed.

The material of this study comes from the following collections:

DAPC $=$ Collection of D. Aguín-Pombo, UMa Madeira, Portugal

MNHN = Muséum national d'histoire naturelle, Paris, France

NHMUK $=$ The Natural History Museum, London, UK

$\mathrm{UMACI}=$ Insect Collection of the University of Madeira, Madeira, Portugal 


\title{
Results
}

\author{
Class Insecta Linnaeus, 1758 \\ Order Hemiptera Linnaeus, 1758 \\ Suborder Auchenorrhyncha Dumeril, 1806 \\ Infraorder Cicadomorpha Evans, 1946 \\ Family Cixiidae Spinola, 1839 \\ Subfamily Cixiinae Spinola, 1839 \\ Tribe Cixiini Spinola, 1839 \\ Genus Cixius Latreille, 1804
}

\section{Cixius wollastoni sp. nov. 1sid:zoobank.org:act:8479B00C-1C4A-4623-A79F-DB646A8EDEE8}

Figs 3D, 4A-N, 5C

\section{Diagnosis}

Cixius species from Madeira differ from other species of the genus in the structure of the aedeagus: (1) the base of the aedeagus is long and rectangular, with a small midventral expansion and a solid ventral spine at its proximal end; (2) they have two different sized spines distally, one on each side of the theca, the largest one on the right is long and arched upwards or laterally and the other is very small, sometimes almost obsolete; (3) the velum is hump-shaped at the base and narrower and more arched apically.

Cixius wollastoni sp. nov. is smaller than $C$. verticalis and larger than C. madeirensis (Table 1). Externally it is very similar to $C$. verticalis in colouration and shape, but the vertex is more acute on the anterior margin and strongly curved on the posterior part. It differs from C. madeirensis in the overall colouration, which is darker with larger and darker punctuations on the wings, and the vertex that is acute. Unlike $C$. verticalis, the lobes of the anal tube in $C$. wollastoni sp. nov. are not much wider medially than laterally, are less curved than in C. madeirensis and are not as wide. Cixius wollastoni sp. nov. differs from the other Madeira Cixius in the following characters of the aedeagus: (1) the basal half of the vellum is subtrapezoidal with a small dorsolateral denticle; the ventrocranial margin of the distal part is almost straight, not curved; (2) the largest movable spine is slender and curved upward; (3) the medioventral expansion of the basal part of the aedeagus is smaller, gently undulating.

\section{Etymology}

The name is derived from Thomas $\mathrm{H}$. Wollaston, in recognition of his contribution to the study of the entomological fauna of Madeira and for collecting of Auchenorrhyncha.

\section{Material examined}

\section{Holotype}

MADEIRA ISLANDS - Santana • $\widehat{\overbrace{}}$ (right wing missing); Ribeiro Frio; 1200 m a.s.1.; 3 Jun. 2004; Élvio Nunes leg.; on Clethra arborea; sweeping net beats: 3(20); Meia Serra Project; MNHN(EH) 24738.

\section{Paratypes}

MADEIRA ISLANDS - Santana 11 (only genitalia glued on label); Corredor Verde; $300 \mathrm{~m}$ a.s.l.; 15 Apr. 2002; Énio B.N. Freitas leg.; on Pteridium aquilinum; MNHN(EH) $24739 \bullet 1$ q; Ribeiro Frio; 1050 m a.s.1.; 24 May 2002; Élvio Nunes leg.; on Laurus azorica; sweeping net $\mathrm{n}^{\mathrm{o}}$ of beats 1(30); Meia Serra Project; MNHN(EH) 24740 • 1 §̊; Ribeiro Frio; 1200 m a.s.1.; 6 Jun. 2003; Élvio Nunes leg.; on Clethra arborea; sweeping net $\mathrm{n}^{\mathrm{o}}$ of beats 2(20); Meia Serra Project; MNHN(EH) 24741 • 1 §ं; Ribeiro 

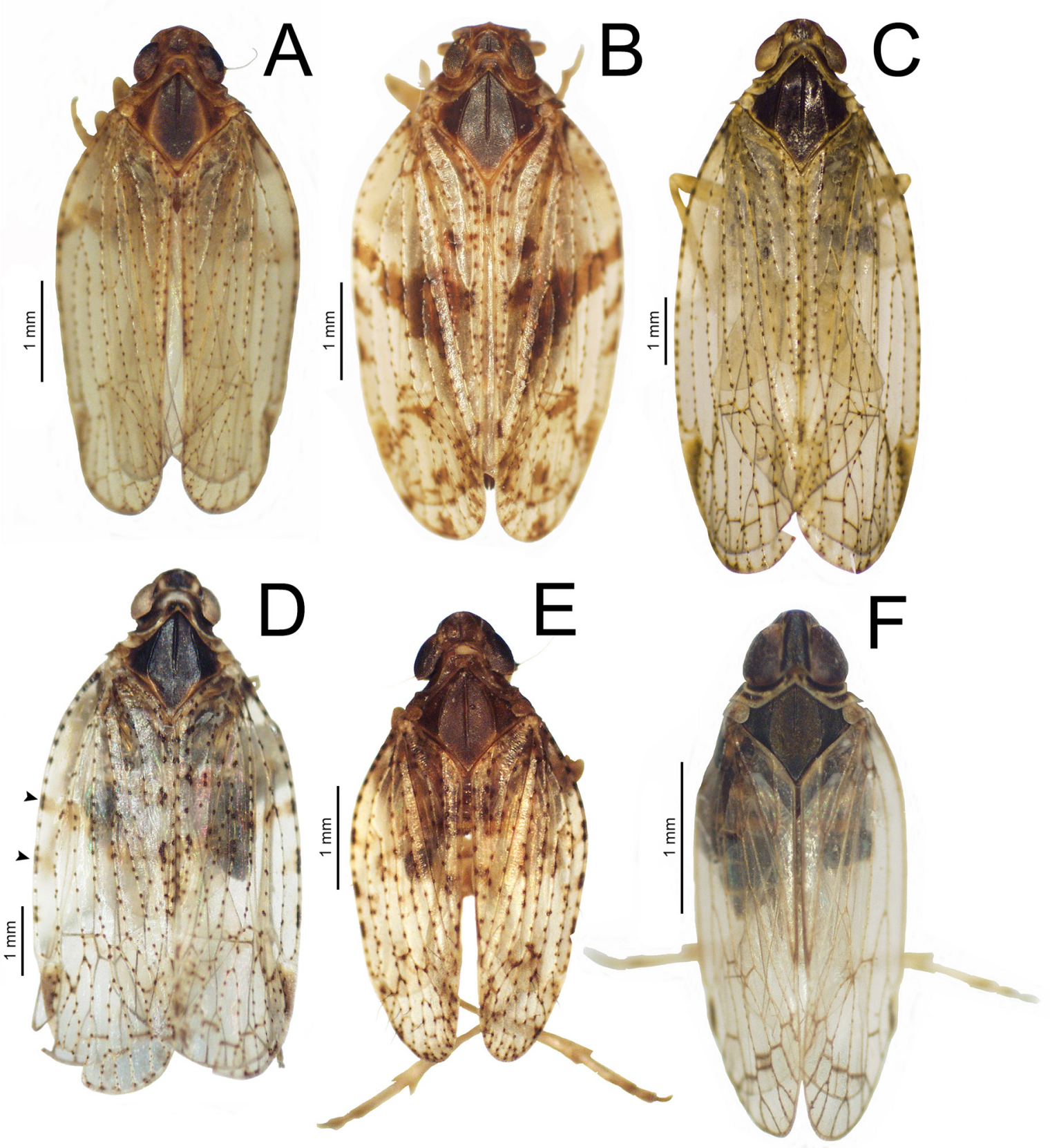

Fig. 3. Habitus. A-B. Cixius madeirensis China, 1938. A. đo from Vereda Paul, 23 Jul. 2002, on Pteridium aquilinum (L.) Kuhn. B. + from Corredor Verde, 16 Apr. 2002, on P. aquilinum. C. Cixius verticalis Noualhier, 1897, đ from Chão da Ribeira, 4 Sep. 1998. D. Cixius wollastoni sp. nov., $\widehat{0}$ from Ribeiro Frio, 24 May 2002, on Digitalis purpurea L. (the arrows indicate the brown stripes). E. Tachycixius chaoensis China, 1938, ô from Ponta de São Lourenço, 11 May 2001, on Suaeda vera Forssk. ex J.F.Gmel. F. Hyalesthes madeires Remane \& Hoch, 1986, ô from Serra de Água, 9 Jul. 2001, on Globularia salicina Lam. 
Frio; 1050 m a.s.1.; 3 Jun. 2004; Élvio Nunes leg.; on Clethra arborea; sweeping net $\mathrm{n}^{\mathrm{o}}$ of beats 2(20); Meia Serra Project; UMACI $-1 \hat{\jmath}$; same collection data as for preceding; sweeping net $\mathrm{n}^{0}$ of beats 1(20); UMACI • 1 गे; Ribeiro Frio; 1050 m a.s.1.; 24 May 2002; Iola Martins leg.; on Digitalis purpurea; sweeping net $\mathrm{n}^{\circ}$ of beats $3(40)$; Meia Serra Project; DAPC $\bullet 1$ क ; same collection data as for preceding; sweeping net $\mathrm{n}^{\mathrm{o}}$ of beats 2(40); UMACI.

\section{Type locality}

Holotype collected along a walking path in the Laurissilva with trees including Laurus novocanariensis, Prunus laurocerasus L., Clethra arborea, and Vaccinium padifolium Sm.

\section{Description}

Body measurements $(\mathrm{mm})$. Holotype: BL (not measurable); length of the left wing $=1.6, \mathrm{ML}=1.6$, $\mathrm{MW}=1.27, \mathrm{PW}=1.47, \mathrm{WL}$ (not measurable). For all specimens see Table 1.

Colouration. Overall colouration dark brown to black (Fig. 3D). Vertex medially with a large black spot reaching the anterior margin and a small yellowish roundish spot on each side. Posterior angles of vertex, lateral shallow pits of the frons, anteclypeus and genae dark brown (Fig. 4A-B). Laterobasal areas above epistomal suture, medial and lateral carinae, postclypeus and lora yellowish. Lateral ocelli pale. Eyes brown-reddish. Pronotum pale brown, medially behind vertex dark brown. Mesonotum and carinae black, posterior margin fulvous. Tegula pale yellow. Tegmina hyaline, veins pale with stigma and setiferous tubercles dark brown (Fig. 5C). Some males and females have brown stripes on costal margin of tegmina which are more distinctive in females (Fig. 3D). In the holotype the band on the first third is larger, wider and oblique towards the clavus. The other is faint and much shorter, reaching the subcostal vein. Legs yellowish but dark brown around tibiofemoral joints. Abdomen, pygofer and lamella of parameres dark brown. Females darker than males with the setiferous tubercles and markings more distinct; lightest specimens with posterior margins of sternita limited by a thin yellowish strip. Gonoplaca dark brown, lightening towards inner lateral margins.

HEAD. Vertex concave, margin anterior acute and posterior parabola-shaped; medially more than 1.5 times shorter than wide at anterior eye margin (Fig. 4B). Pits between vertex and frons shallow. Forehead convex. Frons more than 1.2 times as wide as long, slightly concave on each side of the medial carina; lateral and medial carina ridged; medial carina tapering along the clypeus (Fig. 4A). Epistomal suture wave-shaped. Medial ocellus vestigial, in some specimens obsolete.

THORAX. Pronotum with three carinae distinctly ridged; medial carina short with a deep pit on each side and two shallow depressions in the post lateral margins. Mesonotum with three sharp carinae of similar size; lateral carinae divergent and obsolete towards the apex (Fig. 4B); posterior margin sharply acute and distal area between the lateral carinae an apex slightly concave. Tegmina 2.75 times as long as wide, extends well beyond the apex of the abdomen; bristles along veins sporadic (Fig. 3D). Metatibia with two small lateromedial spines separated from each other about $1 / 3$ of the length of the tibia; the distance from the first spine to tibiofemoral joints is less than $1 / 3$ of the length of the tibia. First metatarsus with 8 spines distally.

Male genitalia. Pygofer lobes are slightly subtrapezoid, the distal margin almost straight (Fig. 4F-G, J). Anal tube shallowly concave at the caudoventral margin; lateral lobes asymmetric and slightly bent distally, the widest sub-triangular part medially almost as large as the thinner part (Fig. 4D-E, H-I). Parameres dilatated distally, the dorsal margin of the lamella semicircular (Fig. 4C). Ventral margin of the aedeagus with a smooth, wave-shaped projection medially; the proximal margin in the form of a semi-arc, bordered by several small spines, the ventral spine larger and hooked, of variable size (Fig. 4K-L). The distal end of the aedeagus with a movable spine on each side (Fig. 4L); the right 


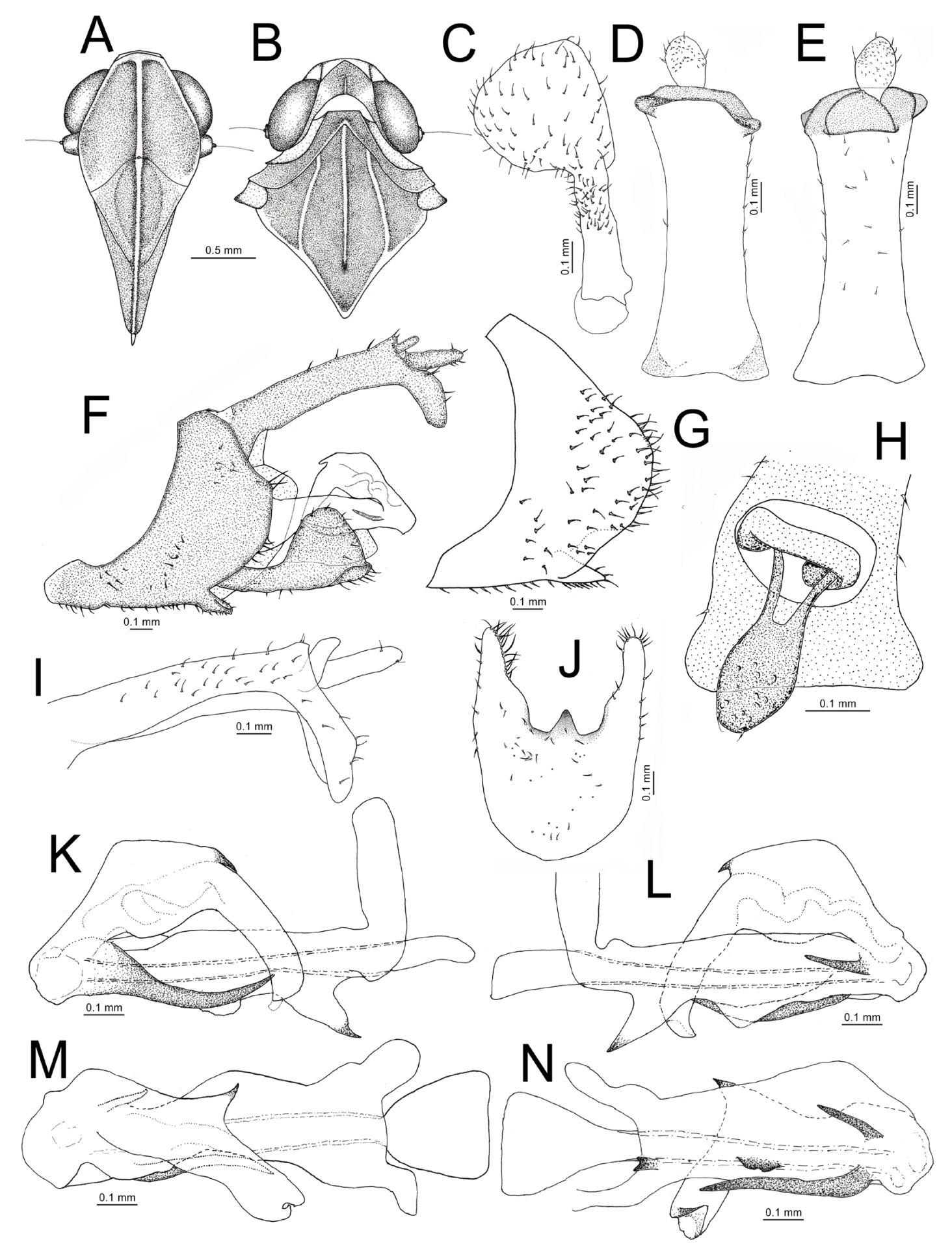

Fig. 4. Cixius wollastoni sp. nov. A-C, G, I. Specimen from Ribeiro Frio, 24 May 2002, on Digitalis purpurea L. D-E, H. Specimen from Ribeiro Frio, 3 Jun. 2004, on Clethra arborea Aiton. F, K-N. Holotype, $\widehat{\jmath}$ (MNHN(EH) 24738). J. Specimen from Ribeiro Frio, 6 Jun. 2003, on C. arborea. A. Head (frontal view). B. Head, pronotum and scutellum (dorsal view). C. Left paramere. D-E. Anal tube (ventral and dorsal view). F. Genitalia. G. Pygofer (lateral view). H-I. Anal tube (caudal and left lateral view). J. Pygofer (ventral view). K-N. Aedeagus (K-L, right and left lateral view; M-N, dorsal and ventral view). 
FREITAS É. \& AGUÍN-POMBO D., Taxonomy of the Cixiidae from the Madeira archipelago

spine, larger and thicker, dorsally directed and slightly curved; the small left spine of variable curvature, sometimes almost obsolete. Velum in repose curved laterally to the right (Fig. 4M-N); the basal half subtrapezoid with a small dorsolateral denticle; apex of aedeagus narrow and long with ventral margin almost straight and apex hook-shaped (Fig. 4K-L).

Female genitalia. As in C. verticalis. The seventh sternite with caudal margin in the form of an inverted truncated trapeze. Gonoplac ensiform, long and pubescent with longer setae on its dorsal margin. Other characters are non-observable.

\section{Distribution and ecology}

Endemic to Madeira Island. It occurs between 300 and $1000 \mathrm{~m}$ of altitude in the areas of northern and southern laurel forests. The specimens were collected from May to June in the endemic tree species Clethra arborea and Laurus novocanariensis, as well as in Pteridium aquilinum ferns, and Digitalis purpurea $\mathrm{L}$.

\section{Remarks}

Males and females of the Cixius species from Madeira often have three brown stripes on the tegmina, more distinctive on females than males. In some specimens like the holotype, the apical band is often not visible. The band patterns when marked resemble those of $C$. madeirensis shown in Fig. 3B. There is also a slight variation in the ventral silhouette of the aedeagus and the length and degree of bending of the two spinose processes.

The aedeagus represented by Lindberg (1961: 54, fig. 4g-i) and erroneously assigned to C. insularis Lindberg, 1954, is very similar to that of $C$. wollastoni sp. nov. In Lindberg's specimens, the large movable spine is also comparatively small and thin and curves smoothly upwards, does not bend distally as in $C$. verticalis and C. madeirensis; the apex of the aedeagus is narrow and long with a hook-shaped tip similar also to $C$. wollastoni sp. nov.; the aedeagal base ends in a long triangular, spine-like process and on its ventral margin there is wave-shaped process similar to that in $C$. wollastoni sp. nov. The lateral lobes of the anal tube and the lamella of parameres are also like in $C$. wollastoni sp. nov. But the flagellum differs; the shape is not subtrapezoidal and is less expanded and the small denticle is missing. However, this part is less chitinous and difficult to visualize; therefore it can easily be overlooked. Lindberg did not mention on which specimens his illustrations were based; therefore, it could be from his own collection or from coll. Wollaston, Lundbland or Frey, who provided samples to him.

Cixius verticalis Noualhier, 1897

Figs 3C, 5B, 6A, C, 7A-N, 8C-D

Cixius verticalis Noualhier, 1897: 79, pl. I, fig. 1.1 (description, illustration of head).

Cixius verticalis - China 1938: 50 (records). - Lindberg 1954: 4-5 (same material as China 1938; illustration of male genitalia and description of aedeagus, misidentified as C. madeirensis); 1961: 54-55 (new records; habitat; new illustrations of male genitalia, but in fact very likely $C$. wollastoni sp. nov.).

Cixius verticalis Noualhier? - Lindberg 1941: 27 [wrong record for Azores], 31 [Madeira record].

\section{Diagnosis}

Cixius verticalis is the largest of the Madeira Cixius (Table 1). The vertex is sharper on the anterior margin than in C. madeirensis. The overall colouration is darker than in C. madeirensis, with larger 
and darker wing punctuations. The lobes of the anal tube in C. verticalis do not bend rostrally as in C. madeirensis. The aedeagus differs in the following characters: (1) the basal half of the velum shows a broad, hump-shaped dilatation; (2) the medioventral expansion of the base of the aedeagus is rounded or subtriangular and less pronounced than in C. madeirensis.

\section{Material examined}

Lectotype (here designated)

MADEIRA ISLANDS $\bullet \widehat{~}\left(\right.$ pinned on a minute pin, $1^{\text {st }}$ left leg missing, abdomen dissected with aedeagus separated, both in a vial with glycerin); "Cixius/verticalis Nlh [handwritten]", "Madère [handwritten]", "C. verticalis [handwritten]/det. RIBAUT"; MNHN(EH) 24138.

\section{Paralectotypes}

MADEIRA ISLANDS • 1 q (pinned on minute pin, a second left leg missing); "Madère"; "C. verticalis/ det. RIBAUT [printed]"; $\mathrm{MNHN}(\mathrm{EH}) 24139 \bullet 1$ ? ${ }^{\wedge}$ (specimen without abdomen, glued on a card); "MUSEUM PARIS/MADĖRE/A. FAUVEL 92-97" [handwritten], "Cixius/verticalis/ det. RIBAUT

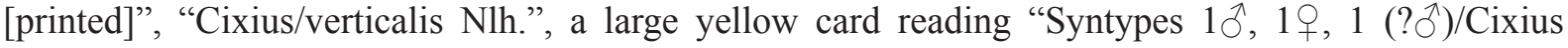
verticalis Nouhalier/[Revue. Ent. 1897:79]”; MNHN(EH) 24140.

\section{Other material}

MADEIRA ISLANDS - Porto Moniz • 1 đ̊; Chão da Ribeira; 540 m a.s.1.; 24 Jul. 1997; Dora Pombo leg; DAPC $\bullet 1 \hat{\delta}$; same collection data as for preceding; DAPC $\bullet 5 \hat{\delta} \hat{\delta}, 1$; ; same collection data

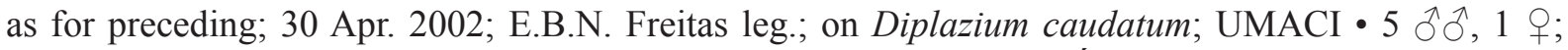
same collection data as for preceding; 450 m a.s.1.; 21 May 2002; Énio B. Freitas leg.; on Persea indica; UMACI 1 ô; same collection data as for preceding; 8 Jul. 1998; I. Silva leg.; on Euphorbia mellifera; UMACI 1 万; same collection data as for preceding; 21 May 2002; F. Reis leg.; on Persea indica; UMACI • 1 ô; Ribeira da Janela; 400 m a.s.1.; 14 Dec. 2001; D. Aguín-Pombo leg.; on Laurus

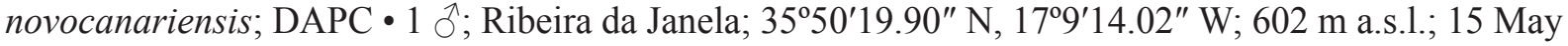
2015; Elisa Teixeira leg.; on native trees; UMACI. - Santana • 1 ô;; Ribeiro Frio; 1000 m a.s.l.; 28 Apr. 2000; A.Mª . João leg.; UMACI.

\section{Redescription}

Body MEASUREMENTS (mm). Lectotype: $\mathrm{BL}=7.81, \mathrm{HW}=1.32, \mathrm{ML}=1.75, \mathrm{MW}=1.5, \mathrm{PW}=1.62, \mathrm{VL}=0.32$. For other specimens see Table 1.

Colouration. Males like C. wollastoni sp. nov. but eyes pale yellow (Figs 3C, 5B), mesonotum glossy; the bands on the tegmina also similar, but vestigial; legs yellowish but the dark brown colour around the tibiofemoral joints extends like a shadow along the tibia. The females are darker than males, as in $C$. wollastoni sp. nov., and the gonoplacs are light brown, being lighter towards the internal lateral margins (Fig. 8C-D).

HeAD. Forehead, vertex, and ocellus as in C. wollastoni sp. nov. but differs from this in the vertex that is more excavated, the anterior margin is more angular, and the parabola, on the posterior margin, is less pronounced (Fig. 7B). Frons is approximately 1.1 times as wide as the height medially (Fig. 7A).

Thorax. Pronotum, mesonotum, tegulae, tegmina, and tibiae as in C. wollastoni sp. nov. (Figs 3C, 5B, 7A-B).

MaLe Genitalia. Lateral lobes of the pygofer concave distally (Fig. 7C-D). The anal tube is as in C. wollastoni sp. nov. but the ventrocaudal margin is slightly concave and divergent, its lobes are subtriangular, and the widest part is distinctly larger medially than at the base (Fig. 7F-H, J). Lamella 

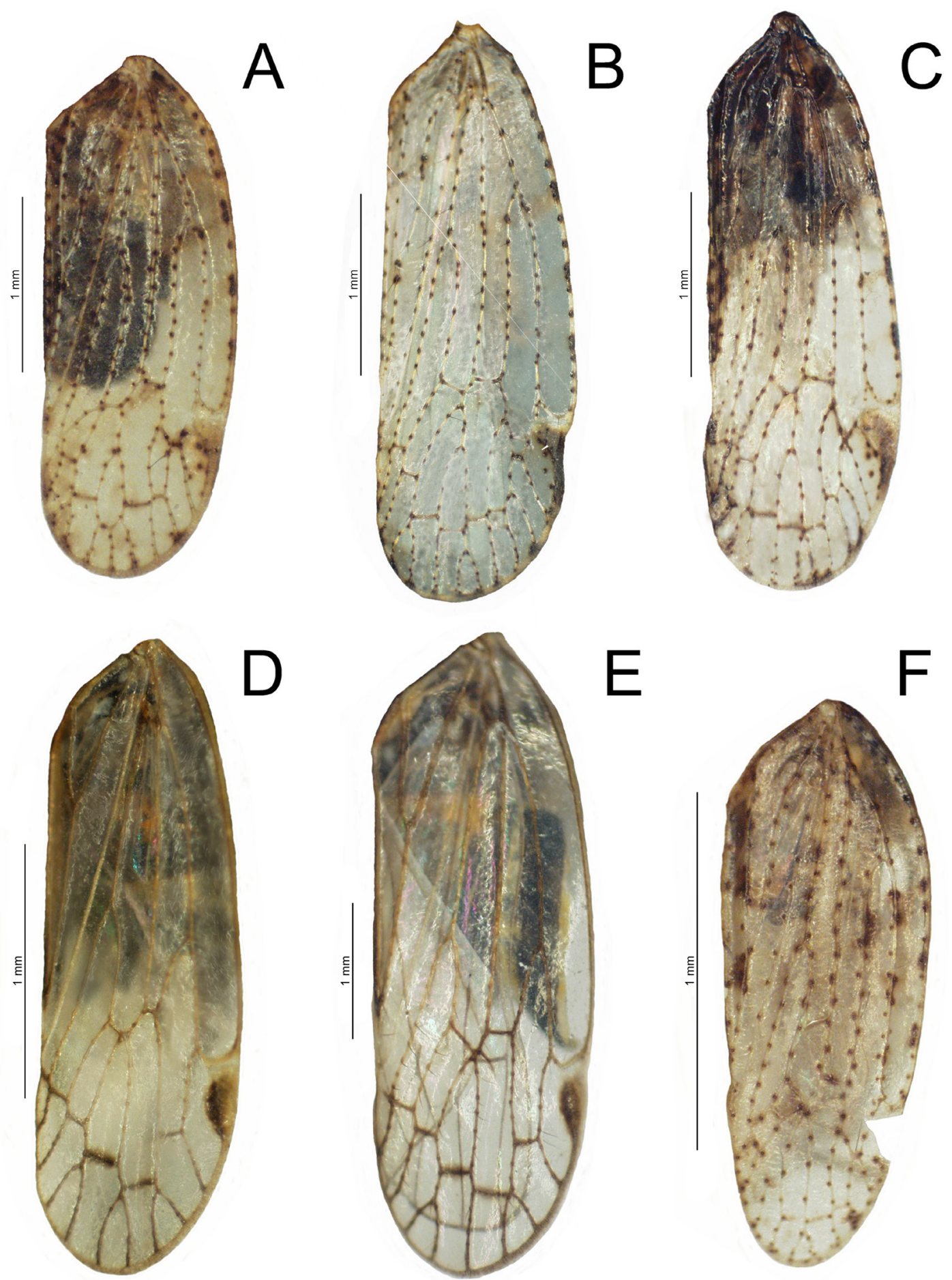

Fig. 5. Male forewings. A. Cixius madeirensis China, 1938 from Vereda Paul, 23 Jul. 2002, on Pteridium aquilinum (L.) Kuhn. B. Cixius verticalis Noualhier, 1897 from Chão da Ribeira, 30 Apr. 2002, on Diplazium caudatum (Cav.) Jermy. C. Cixius wollastoni sp. nov. from Ribeiro Frio, 24 Apr. 2002, on Digitalis purpurea L. D. Hyalesthes madeires Remane \& Hoch, 1986 from Serra de Água, 9 Jul. 2001, on Globularia salicina Lam. E. Hyalesthes portonoves Remane \& Hoch, 1986 from Porto Novo, 16 Apr. 2003, on G. salicina. F. Tachycixius chaoensis (China, 1938) from Ponta de São Lourenço, 11 May 2001, on Suaeda vera Forssk. ex J.F.Gmel. 
of paramere oval, the anterior margin is oblique, and the ventral and posterior margins are slightly concave (Fig. 7I). Basal part of the aedeagus long and rectangular with a small rounded or subtriangular ventromedial projection (Fig. $7 \mathrm{~K}-\mathrm{L}$ ); the ventral spine at the proximal end is triangular; there are two thorns subapically; the right-side is large, variable in size, and sharply bends distally at a $90^{\circ}$ angle; the left spine is almost straight and sometimes slightly curved, but much smaller and thinner than in C. madeirensis (Fig. 7M-N).

Female Genitalia. The shape of the caudal margin of the seventh sternite is truncated (Fig. 8C-D). The anal tube is long and the gonoplac is ensiform and long, reaching the caudal margin of the anal tube, almost touching it from behind (Fig. 8D). Nineth tergite truncated caudally with caudal margins incurved. The wax secreting field reduced, oval and deeply excavated in the middle but not separated by a distinctive crest; long hairs denser near the lateral margin.

\section{Distribution and ecology}

Endemic to the island of Madeira. Due to the successive errors in identification, previous records of this species (Noualhier 1897; China 1938; Lindberg 1941, 1961), should be taken with caution. In this study, adults of this species were collected from medium to high altitudes on the slopes of northern Madeira. Adults can be found from April to October in endemic plants that grow in shaded and humid areas of the evergreen laurel forest, such as Persea indica and Clethra arborea trees, Euphorbia mellifera Aiton shrubs and Diplazium caudatum (Cav.) Jermy ferns. It was also found in hedges and trees that grow in the native forest (Lindberg 1961).

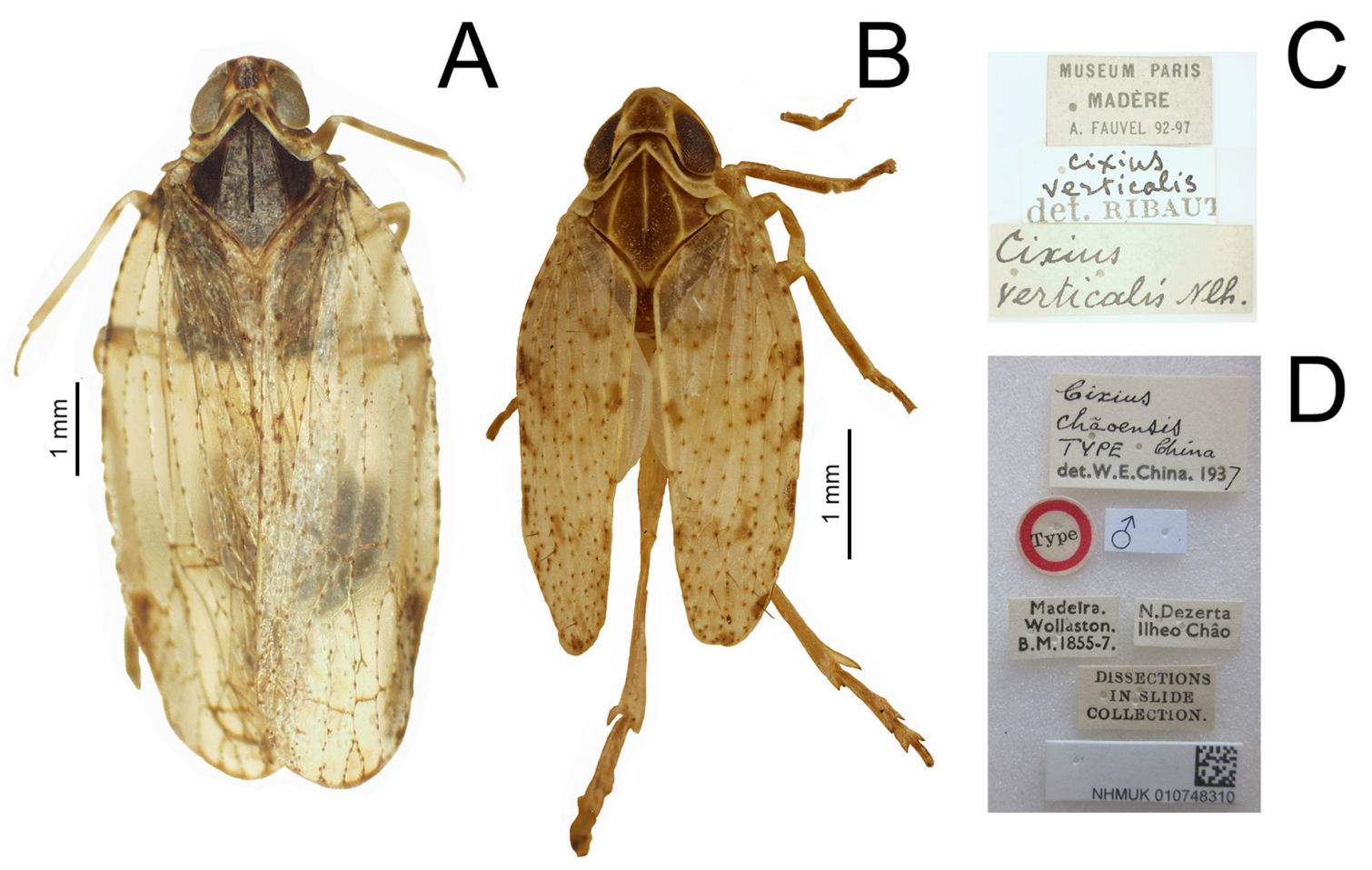

Fig. 6. A, C. Cixius verticalis Noualhier, 1897, lectotype, § (MNHN(EH) 24138). Habitus and label. B, D. Tachycixius chaoensis (China, 1938), lectotype, ô (NHMUK 010748310). Habitus and label. Photographed by Ken Merrifield and kindly provided by Mick Webb (NHMUK). 


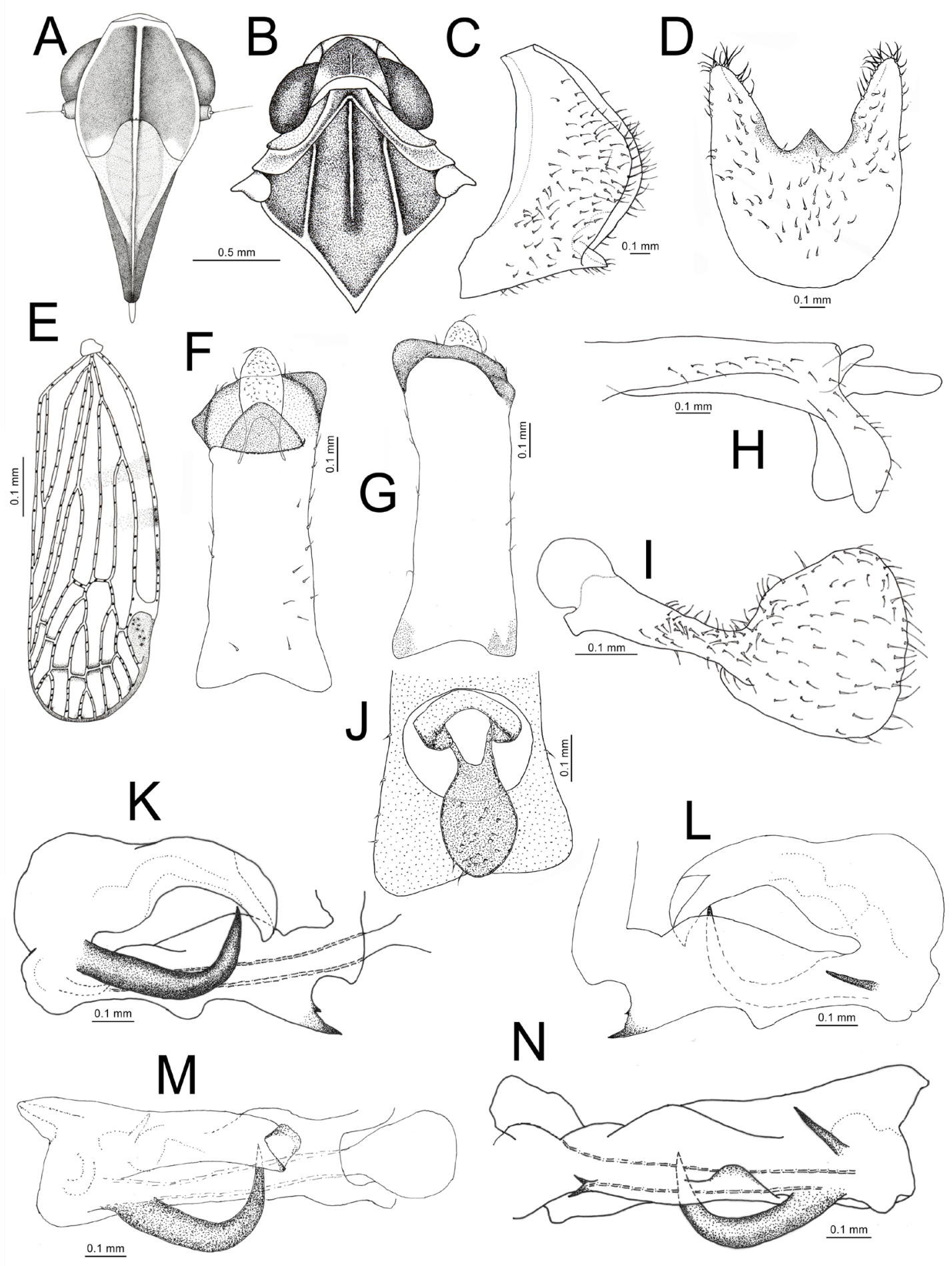

Fig. 7. Cixius verticalis Noualhier, 1897, specimens from Chão da Ribeira. A, C, H. 8 Jul. 1998, on Euphorbia mellifera Aiton. B. 4 Sep. 1998. D-E, J. 30 Apr. 2002, on Diplazium caudatum (Cav.) Jermy. F-G. 4 Aug. 1998. I. 10 Jun. 1998, on Persea indica Spreng. K-N. Lectotype, ô (MNHN(EH) 24138), label without information besides "Madère". A. Head (frontal view). B. Head, pronotum, and scutellum (dorsal view). C-D. Pygofer (lateral and ventral view). E. Right forewing. F-H. Anal tube (dorsal, ventral and left lateral view). I. Left paramere. J. Anal tube (caudal view). K-N. Aedeagus (K-L, right and left lateral view; $\mathrm{M}-\mathrm{N}$, dorsal and ventral view). 


\section{Remarks}

The type material comprises a male, designated as the lectotype, on which Noualhier (1897) based the original description, and two additional specimens, one female and the other of unknown sex. The last two were used to describe the colour and size of the body. The female is shorter (body length = $7 \mathrm{~mm}$ ) than all the female specimens of $C$. verticalis studied (see Table 1); it is more within the range of $C$. wollastoni sp. nov. However, the vertex, deeply excavated, long, with the anterior margin angular, and the sharp carinae are more like the lectotype of $C$. verticalis than the holotype of $C$. wollastoni sp. nov. The body size is larger than in $C$. madeirensis. The original description of $C$. verticalis refers that the points along the tegmina veins are not setiferous, but the setae exist although they are difficult to recognize and easily breakable.

The identification of $C$. verticalis has been difficult because no credible drawings of its genitalia were available. The original description did not provide any and those published later by Lindberg were wrongly attributed to this species. Lindberg (1941: 27), despite having some doubts, identified specimens from the Azores as C. verticalis. Later (Lindberg 1954: 4-5), based on the same material and new specimens collected by Stora and Frey, he concluded that those of the Azores belonged to different species, which he described as $C$. (Sciocixius) insularis and C. (Ceratocixius) azoricus. In the same work, he provided the first illustrations of what he thought was the male genitalia of $C$. verticalis. However, the shape of the aedeagus resembles the genitalia of C. maderensis (Lindberg 1954: 5, figs 7-10), particularly the humped projection of the flagellum and the blunt tip of the apex of the aedeagus. The small spine is also comparatively long and curved. It seems that he wrongly illustrated the specimen(s) of C. madeirensis from the Lundblad collection, which China (1938) had previously studied and identified as $C$. verticalis. In 1961, he studied these specimens again and new material that he had collected in Madeira. Here he provided new records that he assigned to C. insularis, and, again, what he believed to be the first drawings of the male genitalia of $C$. verticalis (China 1938: 54, fig. 4g-i) which are probably $C$. wollastoni sp. nov. (see above). Since none of Lindberg's drawings seem to correspond to $C$. verticalis, the genital structures of this species are illustrated here for the first time.

Cixius madeirensis China, 1938

Figs 3A-B, 5A, 8A-B, 9A-N

Cixius madeirensis China, 1938: 50-51, fig. 21 (description, illustrations, records).

Cixius madeirensis - Lindberg 1961: 55 (records, habitat).

\section{Diagnosis}

This species is easily recognizable by its size, smaller to $C$. wollastoni sp. nov. and C. verticalis, and brown colouration. It differs from the other Madeira Cixius in the following characters: (1) the basal half of the vellum is hump-shaped but is much narrower on the outer margin than in C. verticalis; the apex is blunt, not scythe-shaped as in C. wollastoni sp. nov. and C. verticalis; (2) the medioventral expansion of the theca is digitiform and more conspicuous and longer.

\section{Material examined}

MADEIRA ISLANDS - Porto Moniz • 2 क $q$; Chão da Ribeira; 500 m a.s.1.; 30 Apr. 2002; Énio

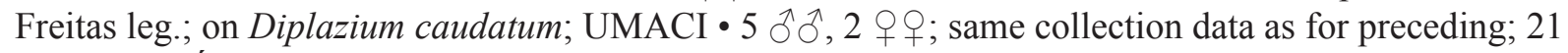
May 2002; Énio Freitas leg.; UMACI • 1 §; same collection data as for preceding; 11 Apr. 2003; Dora Pombo leg.; DAPC • 1 § ; same collection data as for preceding; 28 Jul. 1997; I. Silva leg.; UMACI • 1 + ; Ribeira da Janela; 800 m a.s.1.; 12 Sep. 2001; Énio Freitas leg.; on Pteridium aquilinum; UMACI

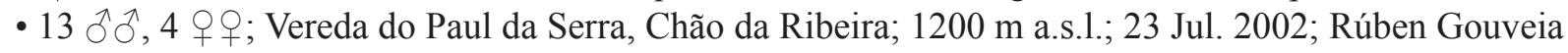



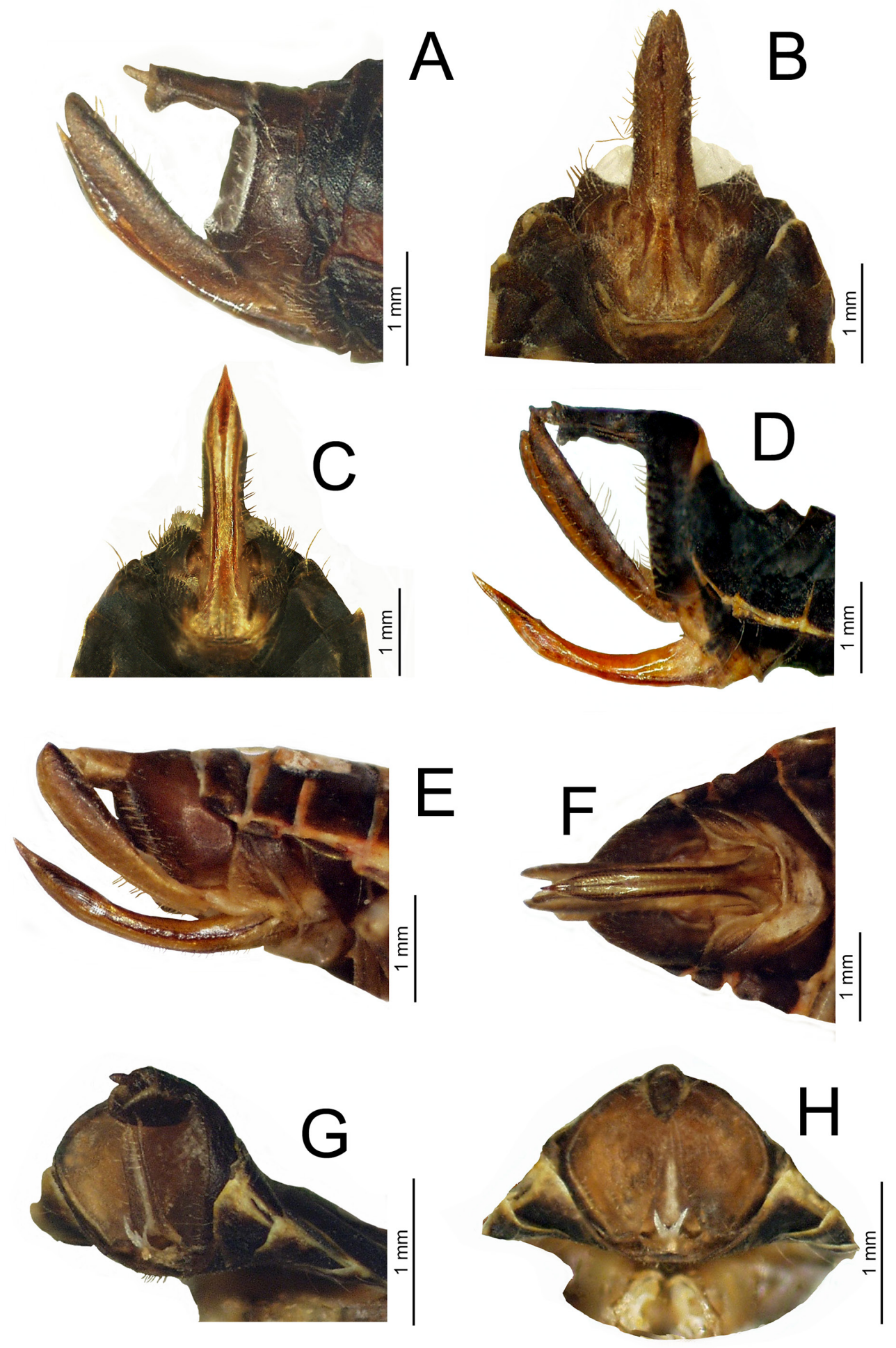

Fig. 8. Female genitalia. A-B. Cixius madeirensis China, 1938 from Vereda do Paul da Serra, 23 Jul. 2002, on Peteridium aquilinum (L.) Kuhn. C-D. Cixius verticalis Noualhier, 1897 from Chão da Ribeira (500 m a.s.1.), 30 Apr. 2002, on Diplazium caudatum (Cav.) Jermy. E-F. Tachycixius chaoensis (China, 1938) from Ponta de São Lourenço, 11 May 2001, on Suaeda vera Forssk. ex J.F.Gmel. G-H. Hyalesthes portonoves Remane \& Hoch, 1986. G. Specimen from Porto Novo, 25 Apr. 2003, on G. salicina Lam. H. Specimen from Cristo Rei, 26 Apr. 1998, on G. salicina. 
leg.; on P. aquilinum; UMACI. - São Vicente • 1 क; Chão Louros; 710 m a.s.1.; 9 May 2000; Joana Barreto leg.; UMACI. - Santana • 1 J $\delta^{\lambda}$ Levada Ribeiro Frio, Portela; 1000 m a.s.1.; 9 Aug. 2001; Énio Freitas leg.; on Clethra arborea; UMACI • 1 ô; Pico das Pedras, Queimadas; 800 m a.s.1.; 7 Sep. 2001; Énio Freitas leg.; on Hydrangea macrophylla; UMACI • 1 ते; same collection data as for preceding; Fábio Reis leg.; on P. aquilinum; UMACI • 1 क; Ribeiro Frio; 1000 m a.s.1.; 12 Jun. 2002; Énio Freitas leg.; on C. arborea; UMACI.

\section{Redescription}

Body MEASUREMENTS (mm). See Table 1.

Colouration. General light golden brown coloration (Fig. 3A-B). Vertex light brown, most specimens have two small paler spots that fade to the level of the anterior margin of the eyes (Fig. 9B). Areolar carinae dark brown. Lateral pits on the frons, clypeus, carinae, genae, lora and the $2^{\text {nd }}$ segment of the antenna, yellowish to light brown, often darker in females. Lateral ocelli glowing yellow. Reddish-brown eyes. Pronotum and tegula as in C. wollastoni sp. nov. Mesonotum brownish-black; lateral carinae, posterior margins and posterolateral margins close to tegula fulvous; in lighter individuals, the area between the lateral carinae is light brown and, in females, it is almost entirely brown. Tegmina yellowish and translucent; pale veins with brown setiferous tubercles; stigma yellowish to dark brown (Figs 3A-B, 5A). Some males and females have three narrow faint brown oblique stripes (Fig. 3B). The band on the first third is larger, wider and bifurcates from the middle, giving rise a short oblique band towards $1 / 3$ of clavus base, and another reaching the clavus lateromedially. The last band forms a dark brown spot below the claval vein fork. The other two strips are short, reaching the subcostal vein. The females are darker than the males and the setiferous tubercles and markings are also more distinctive (Fig. 3A-B); legs, abdomen, and tegmina as in C. wollastoni sp. nov. but, in darker specimens, the brown marks of the tegmina are more intense and extensive.

HEAD. Vertex apex from round to slightly angular (Fig. 9B); posterior margin roundish and about 1.8 times as wide as in the anterior margin of eyes as long. The medial carina of the frons ridged, tapering along clypeus. Epistomal suture wave-shaped, the crest is lower than in C. wollastoni sp. nov. and C. verticalis (Fig. 9A). Medial ocellus reduced or obsolete.

Thorax. Pronotum, mesonotum, tegula, setiferous tubercles along the veins and lateral spines of the metatibiae and the first metatarsus as in $C$. wollastoni sp. nov., but the tegmina is almost 2 times as long as wide (Fig. 5A).

MaLE Genitalia. Lateral lobes of the pygofer roundish with distal end more or less truncated, similar to a trapezium (Fig. 9F, H). The caudoventral margin of the anal tube concave (Fig. 9G), lateral lobes arc-shaped, wider distally and bent rostrally (Fig. 9J). Lamella of the parameres subtriangular, gradually expanding ventrodistally; proximal margin almost straight and distal margin convex (Fig. 9I). The vellum of aedeagus and basal thorns as in $C$. verticalis but the smallest spine longer and more curved; expansion of vellum hump-shaped in its basal half; apex blunt. The proximal margin of theca ends in a solid ventral spine like a finger of variable size, while the ventromedial projection is large and digitiform (Fig. 9K-N).

Female Genitalia. Seventh sternite with truncate inverted caudal margin (Fig. 8B). Gonoplac ensiform and curved upwards; long, about 5 times as long as wide, reaching almost the level of the dorsal margin of the anal tube and exceeding this in half of its length; the dorsal margin pubescent (Fig. 8A). Nineth tergite truncated caudally. Wax secreting field ellipse-shaped and shallowly excavated, approximately 1.5 times as wide as long; not separated medially by a distinctive ridge; scattered long hairs denser near the mediodorsal margin. 


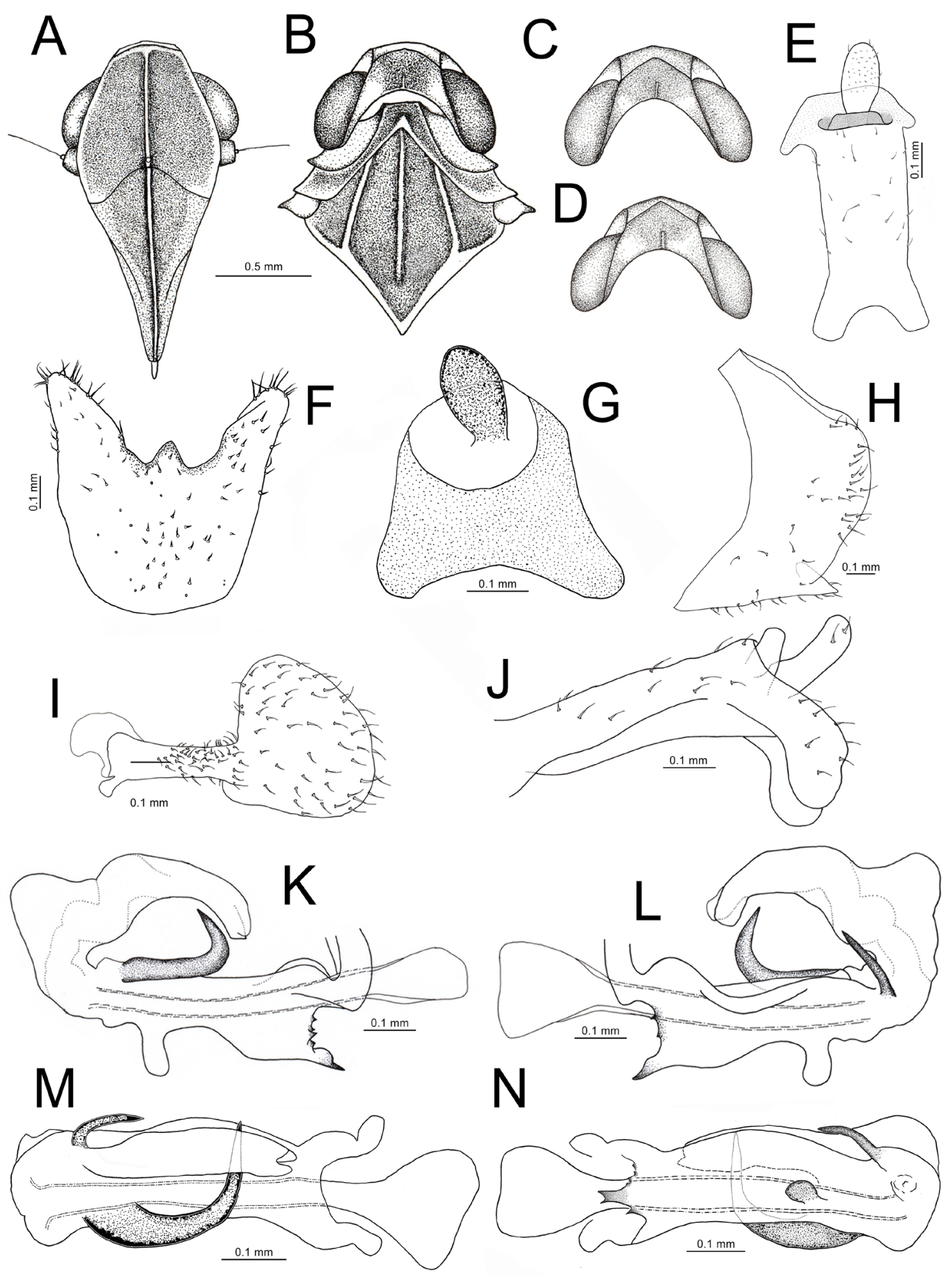

Fig. 9. Cixius madeirensis China, 1938. A-G, I-N. Specimens from Vereda do Paul, 23 Jul. 2002, on Pteridium aquilinum (L.) Kuhn. H. Specimen from Chão da Ribeira, 28 Jul. 1997. A. Head (frontal view). B. Head, pronotum, and scutellum (dorsal view). C-D. Head (dorsal view). E. Anal tube (dorsal view). F. Pygofer (ventral view). G. Anal tube (caudal view). H. Pygofer (lateral view). I. Left paramere. J. Anal tube (left lateral view). K-N. Aedeagus (K-L, right and left lateral view; M-N, dorsal and ventral view). 


\section{Distribution and ecology}

Endemic to Madeira Island. Widespread in north and south Madeira; occurs in wet areas of laurel forest between 500 and $1200 \mathrm{~m}$. Adult specimens were collected from April to September preferentially on Clethra arborea trees and on the fern Diplazium caudatum, an endemic species of Macaronesia, and were also found on Pteridium aquilinum ferns and Hydrangea macrophylla (Thunb.) Ser. bushes. This species was reported by Lindberg exclusively from native vegetation (Lindberg 1961).

\section{Remarks}

The distal margin of the anal tube, style, and aedeagus are very well shown by China (1938), except that the flagellum hump is more pronounced than in China's description, possibly because this thin and almost transparent membrane is difficult to observe. In contrast, Lindberg's drawings (1954), which he attributed to $C$. verticalis (see above), show the hump characteristic of the flagellum and that the ventral process is smoother than in China's illustrations. The blunt apex of the aedeagus, the small curved right lateral spine and the ventral spine-like projection of the proximal margin of the base depicted by China and Lindberg are similar, but the parameres and the anal tube are different.

The values of BL, MW, ML and WL in males and females of $C$. madeirensis are smaller than in C. verticalis (Table 1) including $\mathrm{PW}$, the only measurement with some degree of overlap (Welch t-test, $t(23.98)=68.24, p<0.01)$.

Genus Tachycixius Wagner, 1939

Tachycixius chaoensis (China, 1938) comb. nov.

Figs 3E, 5F, 6B, D, 8E-F, 10A-M

Cixius chaoensis China, 1938: 51-52, fig. 22 (description, illustrations, records).

Cixius chaoensis - Lindberg 1961: 55 (records).

\section{Diagnosis}

Tachycixius chaoensis differs from species of the same genus in the form of aedeagus: (1) the velum has a narrow, hump-shaped expansion at the base, and the apical part is arched and thinner than at base; the apex forks into a straight spine-like dorsal projection and a larger scythe-shaped ventral expansion sharply bent to the left; (2) on each side, the basal part of the aedeagus has two small and thin spines strongly curved inward. There are four endemic species of Tachycixius in the Canary Islands grouped in the T. canariensis group (Holzinger 2000). Tachycixius chaoensis differs from them in: (1) the vellum which has a hump-shaped expansion and the apex is bifurcated, not blunt; (2) the movable spines are of similar size and are on each side of the theca, and strongly curved inward; they are also smaller and thinner than in the Canarian species; (3) the medioventral expansion of the theca has a wave-crested shape, and the proximal end is concave and ends in a solid, thin and inwardly curved ventral spine.

\section{Material examined}

Lectotype (here designated) (Fig. 6B, D)

MADEIRA ISLANDS - Desertas Islands, Ilhéu Chão $\bullet \widehat{~(g l u e d ~ o n ~ a ~ c a r d ~ w i t h ~} 1^{\text {st }}$ left tibia and tarsi glued separately (Fig. 6B, D) and abdomen dissected (in a separated dissection slide), bearing seven labels); a black rectangular label (handwritten) reading "Cixius/châoensis/TYPE China/[printed] det. W.E.China.1937"; a white round label with red printed circle, in the center of this with black

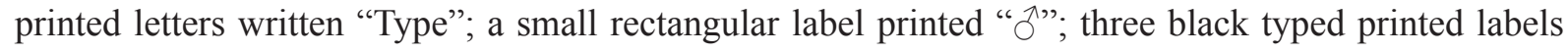
reading "Madeira./Wollaston./B.M.1855-7."; "N.Dezerta/Ilheo Châo"; "DISSECTIONS/IN SLIDE/ 
FREITAS É. \& AGUÍN-POMBO D., Taxonomy of the Cixiidae from the Madeira archipelago

COLLECTION."; a rectangular label with QR symbol and reading "NHMUK 010748310"; NHMUK 010748310 .

Paralectotypes

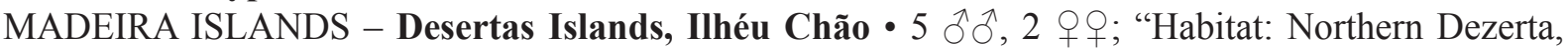
(Ilheo Chão)", each labelled "paratype"; NHMUK.

\section{Other material}

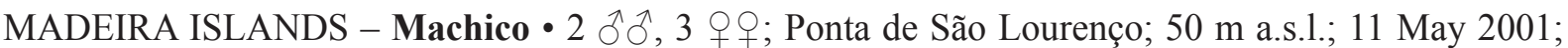
Sara Machado leg.; on Suaeda vera; UMACI.

\section{Redescription}

Body MEASUREMENTS (mm). See Table 1.

Colouration. Males overall colouration light brown, females darker (Fig. 3E). Vertex brown with two paler oval spots at the level of anterior margin of eyes; areolar carina dark brown. Frons and medial ocellus yellowish-brown in males and darker in females. Postclypeus yellowish medially with outer margins darker. Anteclypeus brown, slightly lighter medially; in females, the clypeus is darker. Genae, lora and $2^{\text {nd }}$ antennal segment dark brown. Lateral ocelli golden brown. Eyes blackish brown. Pronotum amber yellow, often light brown medially behind vertex and at posterior angles. Mesonotum brown or dark brown, in some specimens the carinae and posterior margin lighter. Tegula pale brown to light brown. Tegmina translucent, whitish; longitudinal veins pale (Figs 3E, 5F). Some specimens have a darker obliquus strip at $1 / 3$ of the base. Stigma is whitish to dark brown. Wing markings in males reduced and the strips lighter or unnoticeable; legs light brown to brown with varying degrees of shade. Colouration of the abdomen in males and females as in C. madeirensis.

HEAD. Vertex anteriorly tongue-shaped and concave, and posteriorly trapeze-shaped (Fig. 10B); medially short, about $3 / 4$ times as long as wide at the level of anterior eyes margin. Medial carina of the frons smooth, reaching the posterior margin of postclypeus (Fig. 10A). Epistomal suture parabola-shaped, the height of the crest-wave about $1 / 3$ of its width at the base. Lateral pits between the vertex and forehead shallow. Medial ocellus reduced or obsolete.

Thorax. Pronotum and carinae as in C. madeirensis (Fig. 10B). Lateral carinae of mesonotum 2 times more separated distally than basally; length of medial carina about $2 / 3$ of the mesonotum length; the distal area between lateral carinae slightly concave. Tegmina short, narrowing to its distal end; 2.5 times as long as wide in its widest part (Fig. 5F); in females the tegmina are slightly shorter than the abdomen length; bristles along veins sporadic. Metatibia with 3 small lateral spines; $1^{\text {st }}$ spine located near tibiofemoral joints; the other two spines separated from each other by about $1 / 4$ of the tibia length. First metatarsus with 6 spines distally.

Male Genitalia. Pygofer lobes form an elongated parabola (Fig. 10H). Anal tube asymmetric ventrocaudally, with the caudal margin slightly concave laterally (Fig. 10E); lateral distal lobes thumblike with apex roundish; they bend ventrally with the distal part wider than at the base. Anal style globular, pear-shaped as the cactus fruit (Fig. 10F). Paramere tongue-shaped distally; lamella higher than wide at the base with ventral margin convex and proximal margin slightly oblique (Fig. 10G). Right ventral margin of the aedeagus base with two cranially curved lateroventral spines (Fig. 10J-K); the largest, of variable length, is on the anterior margin, and the thinnest is in the center (Fig. 10J); the anterior margin of the aedeagus base is semi-arched and has a row of small spines, variable in number. The aedeagus base has distally two small hooked spines directed toward each other (Fig. 10J-K). Velum hump-shaped with ventrodistal margin curved inwards; apex bifurcated, the largest portion scythe- 


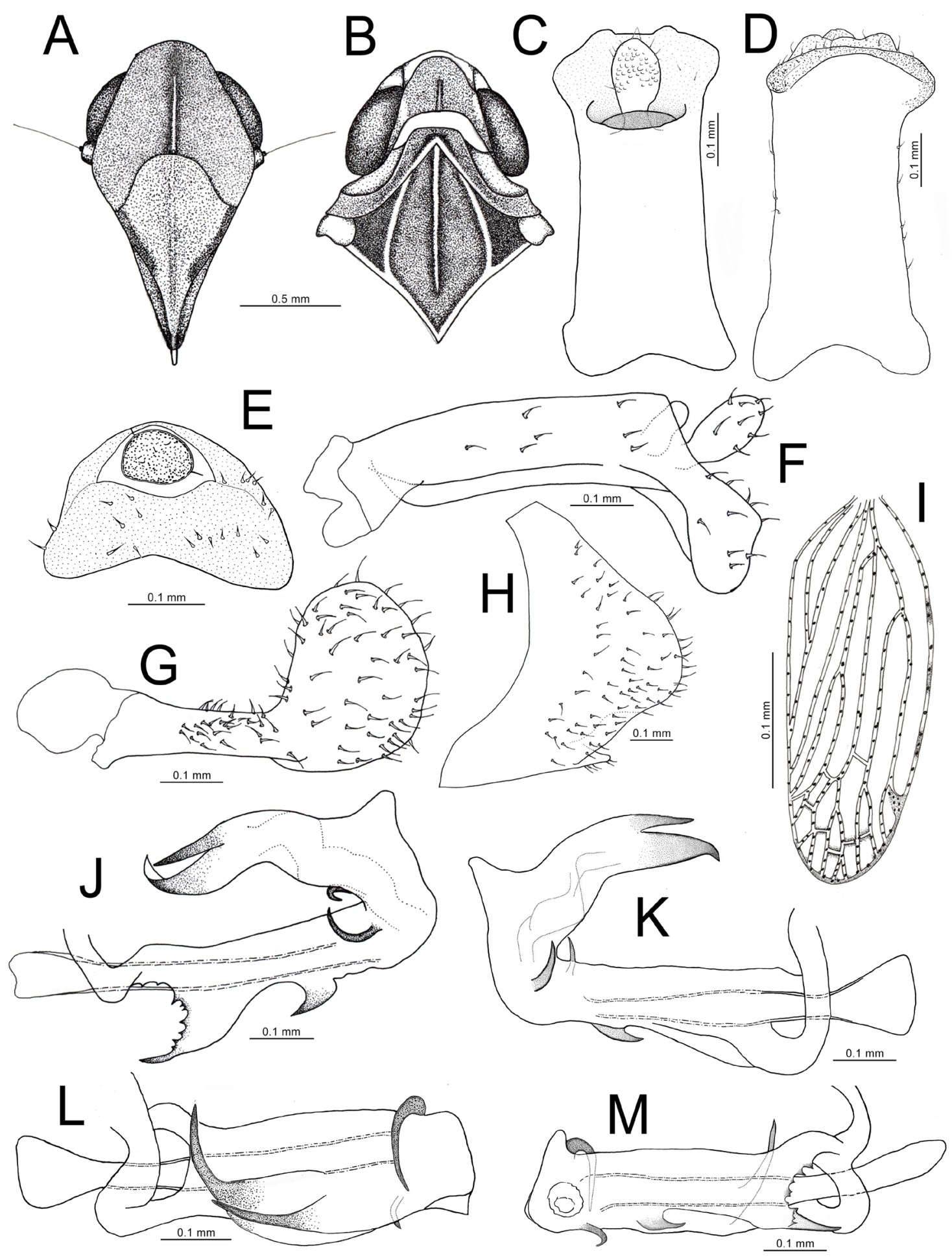

Fig. 10. Tachycixius chaoensis (China, 1938). Specimens from Ponta de São Lourenço, 11 May 2001, on Suaeda vera Forssk. ex J.F.Gmel. A. Head (frontal view). B. Head, pronotum, and scutellum (dorsal view). C-F. Anal tube (dorsal, ventral, caudal and left lateral view). G. Left paramere. H. Pygofer (left lateral view). I. Right forewing. J-M. Aedeagus (J-K, left and right lateral view; L-M, dorsal and ventral view). 
shaped, bent sharply to the right; dorsally the shortest spine is directed to the apex of the inferior process (Fig. 10J-M).

Female Genitalia. Caudal margin of the seventh sternite concave (Fig. 8F). Gonoplac wider distally, about 4.5 times as long as wide, with thin, small scattered setae, mainly on the ventral margin. Gonoplac ensiform, slightly curved upwards up to the dorsal margin of the anal style, touching it behind (Fig. 8E). Lateral margins of the IX tergite distinctly incurved caudally, leaving in the middle a thin channel deeply excavated.

\section{Distribution and habitat}

Restricted to the semi-arid coastal habitats, on the peninsula of the extreme eastern end of Madeira Island. It was only known on the rocky table-like islet of the Ilhéu Chão (China 1938; Lindberg 1961). It is probably monophagous on the halophyte Suaeda vera. As in our case, Wollaston collected specimens of this species in May (11 May 1959) (Lindberg 1961).

\section{Remarks}

In this study, Cixius chaoensis is transferred to Tachycixius, due mainly by the presence of tubercles on the apical margin between veins; hindwings without the protrusion at the end of $\mathrm{Cu} 2$; two lateroventral spines on the left margin of the aedeagus basal-directed and the absence of a medial keel.

The aedeagus is like that represented by China, except for the ventral process of the apex which is more curved to the right, and the distal margin of the parameter which is more rounded. Most of the specimens examined do not show the three wing bands reported by China (1938).

China (1938) did not designate a holotype. However, he described both male and female and mentioned:

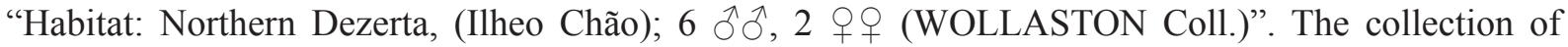
Wollaston is in the Natural History Museum of London. The curator of Hemiptera of this museum, M.D. Webb, found the 8 specimens of the type series which consist of a male labelled "type" and 7 (5 males and 2 females) each labelled "paratype". The specimen labelled "type" is designated here as lectotype. The specimen was studied by photo (NHMUK).

Tribe Pentastirini Emeljanov, 1971

Genus Hyalesthes Signoret, 1865

Hyalesthes madeires Remane \& Hoch, 1986

Figs 3F, 5D, 11A-M

Hyalesthes madeires Remane \& Hoch, 1986: 131-133, 148-149, figs 13-16 (records, description, illustration of male genital structures).

Hyalesthes angustulus - Lindberg 1941: 31 (records, misidentification).

Hyalesthes flavipennis - Lindberg 1961: 54-55, fig. 4 (misidentification).

Hyalesthes madeires - Hoch \& Remane 1985: 141-142, 425, figs 65d-76d.

\section{Diagnosis}

The aedeagus of the H. angustulus species group to which H. madeires belongs (Hoch \& Remane 1985) have a somewhat simpler configuration than other species of the genus. The base of the aedeagus is long, rectangular, obliquely crossed by two long spines caudally directed on the left side. $H$. madeires differs from other species in this group in the following characters: (1) the two long oblique dorsocaudal thorns converge and sometimes cross distally; (2) on the left lateral side, the upper spine is longer than 
the ventral spine and extends distally over the ventral margin of the aedeagus, while the ventral thorn is more slender than the dorsal. Externally, H. madeires is very similar to H. portonoves but the vertex in males is shorter and the lateral margins are usually divergent, not parallel. The male genitalia of $H$. madeires differ also from those in $H$. portonoves in the thickness and curvature of the thorns; the dorsal thorn is wider than the ventral thorn and both converge, the opposite of $H$. portonoves.

\section{Material examined}

MADEIRA ISLANDS - Câmara de Lobos • 1 đ ; Curral das Freiras; 613 m a.s.1.; 28 May 2001; Fábio

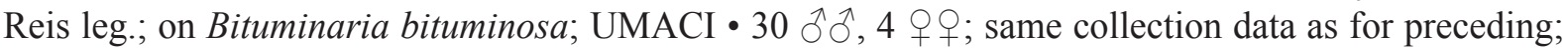
Énio Freitas leg.; on Globularia salicina; UMACI 1 o; same collection data as for preceding; Fábio Reis leg.; on Hyparrhenia hirta; UMACI • 1 ; ; same collection data as for preceding; 20 Aug. 2001; Énio Freitas leg.; on G. salicina; UMACI $\bullet 2 \hat{\jmath}$; same collection data as for preceding; Fábio Reis leg.; UMACI. - Ponta do Sol • $2 \hat{\partial} \widehat{\partial}, 4$ 9 우 Levada Nova; 250 m a.s.l.; 13 Jul. 2001; Énio Freitas leg.; on G. salicina; UMACI • $3 \hat{\delta} \widehat{\partial}, 7$ q $\propto$; same collection data as for preceding; Fábio Reis leg.; on G. salicina; UMACI • $2 \widehat{\partial}$; same collection data as for preceding; Énio Freitas leg.; on Deschampsia argentea; UMACI. - Ribeira Brava $\bullet 8$ $\widehat{\partial}, 10$ 우; Serra de Água; 700 m a.s.1.; 9 Jul. 2001; on G. salicina; UMACI.

\section{Redescription}

Body MEASUREMENTS (mm). VW: males: $0.23-0.30,0.27 \pm 0.02(\mathrm{n}=21)$; females $0.28-0.35,0.31 \pm 0.02$ $(\mathrm{n}=13)$. See also Table 1.

Colouration. Vertex glowing black; areolar carina pale yellow (Fig. 3F). Triangular shallow pits above frons, genae, lora and clypeus black glowing; marginal carinae of the frons pale yellow; in the widest area, two light yellow to golden brown oval spots at each side of the epistomal suture. Second antennal segment yellow ochre. Carinae of the pronotum pale yellow; posterolateral angles and medial-lateral pits behind vertex dark grey. Mesonotum is glowing black, narrowly brown yellow in the lateral angles behind the tegula and apex. Eyes fulvous; lateral ocelli light yellow to fulvous. Tegula pale yellow. Tegmina hyaline (Fig. 5D); veins yellow ochre with some longitudinal and transverse apical veins, pale brown; the expression of colouration varies. Stigma entirely pale brown and outer margins pale ochre; legs faded brown, lighter on the femorotibial joints, hind tibia yellow, in some specimens with fine brown stripes along the lateral grooves. Tarsi of forelegs, middle legs, and apical tarsus of the hindlegs brown. In males, abdominal segments black and genital segments brown ventrally. Pygofer pale to red orange ventrally. In females, abdominal segments black, red orange medially and narrowly pale on the margins.

HEAD. Vertex between eyes shorter than in H. portonoves; at the posterior margin approximately 1.7 times as long as than wide (Fig. 11B); lateral margins often divergent posteriorly and apex parabola-shaped; the ridge of the carinae tapering towards the apex. Subtriangular lateral pits between the vertex and forehead shallow. Forehead convex. Length of the frons 1.5 times longer than wide medially (Fig. 11A); lateral carinae ridged, tapering along the distal half of postclypeus; medial carina distinct, of variable length, tapering towards the widest part of the forehead. Frontoclypeus conspicuous. Epistomal suture parabola-shaped but not well delimited. Medial ocellus is vestigial or obsolete.

Thorax. Pronotum with three distinct carinae; medial carina short, delimiting anteriorly two small pits laterally; posterior carinae divergent, forming two shallow depressions in the posterolateral margins (Fig. 11B). Mesonotum with five carinae; the intercostal carinae parenthesis-shaped, from faded to obsolete, do not touch the medial and costal carinae but sometimes reach the anterior margins of mesonotum; costal carinae slightly arched caudally, reaching the anterior margin of pronotum and the posterior margin of mesonotum; medial carina of variable length, almost as long as the costal carinae. 


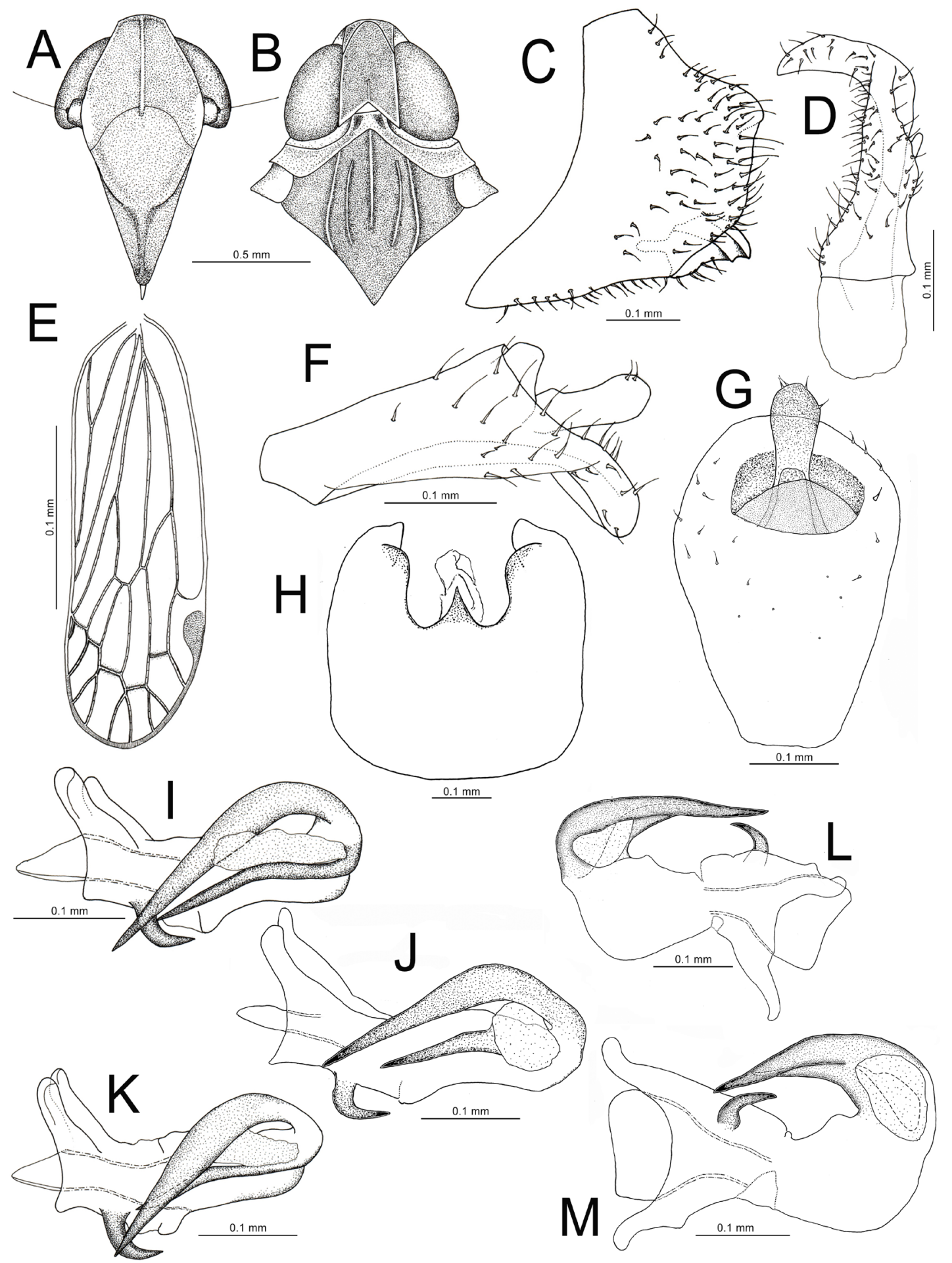

Fig. 11. Hyalesthes madeires Remane \& Hoch, 1986. A-C, E. Specimens from Serra de Água, 9 Jul. 2001, on Globularia salicina Lam. D. Specimen from Levada Nova Ponta do Sol, 13 Jul. 2001, on G. salicina. F, I. Specimens from Curral das Freiras, 20 Aug. 2001, on G. salicina. G-H, J-M. Specimens from Curral das Freiras, 28 May 2001, on G. salicina. A. Head (frontal view). B. Head, pronotum and scutellum (dorsal view). C. Pygofer (left lateral view). D. Left paramere. E. Right forewing. F-G. Anal tube (left lateral and dorsal view). H. Pygofer (ventral view). I-M. Aedeagus (I-K, left lateral view; $\mathrm{L}-\mathrm{M}$, dorsal and ventral view). 
Tegula developed. Tegmina extend well beyond abdomen apex, nearly 3 times as long as wide and with sporadic bristles along veins (Fig. 3F). Hind tibia with 1 or 2 small lateral spines, the largest medial and the other, often faded or obsolescent, near the femorotibial joints. The distal end of the first metatarsus with 7 spines.

Male genitalia (see also Hoch \& Remane 1985). Pygofer lobes subtrapezoidal, about $3 / 2$ wider ventrally than in the widest median half (Fig. 11C, H). The distal part of the anal tube, in lateral view, almost 3 times as wide as the proximal; ventrolateral margin divergent, slightly curved caudally towards the apex and rounded distally. Anal style digitiform, apically slightly globular (Fig. 11F-G). Parameres scythe-like distally, of variable curvature (Fig. 11D); the length of the scythe-like part is half of the paramere length. Aedeagus tubular expanded dorsocaudally in a slightly chitinized projection. Far basally, on the left lateroventral side of the aedeagus base, there is a short, curved thorn of variable size that is caudally directed (Fig. 11I-M). Dorsocaudally from the left side of the aedeagus rise two long oblique thorns directed caudally; these bend strongly to the left side and extend across $1 / 4$ of the aedeagus length; they converge and are sometimes crossed distally (Fig. 11K); the dorsal thorn is straight and tapers to the apex; this is longer, wider and thicker than the ventral horn and exceeds it distally as well as the ventral margin of the aedeagus. The ventral thorn is of variable size, being weakly arched medially and distally oblique; the basal half is parallel to the aedeagus base. But there are intraspecific differences, particularly in the length and curvature of the aedeagus thorns. These can overlap or not at the terminal end (Fig.11I-K).

Female genitalia. As in $H$. portonoves (Fig. 8G-H).

\section{Distribution and ecology}

Endemic to Madeira Island. Widespread on the northern and southern slopes, from low altitudes up to $700 \mathrm{~m}$. Occurs in thermophilic coastal areas and ravines where Globularia salicina Lam. grows, but also in areas with continuous water supply. Adult specimens were collected from May to August on two endemic plants, G. salicina and Deschampsia argentea Lowe, and on the widespread Bituminaria bituminosa (L.) C.H.Stirt. It was also found on Echium L., Rubus L. and Euphorbia L. (Hoch \& Remane 1985; Remane \& Hoch 1986).

\section{Remarks}

The Hyalesthes angustulus species group comprises five species (see Hoch \& Remane 1985). Two of them are endemic to the Canary Islands, H. flavipennis and H. teno Remane \& Hoch, 1986, and two others are endemic to the island of Madeira, $H$. madeires and $H$. portonoves. The last species, H. angustulus, occurs in the Canary Islands and North Africa.

Horváth (1909) described H. angustulus and H. flavipennis from the Canary Islands but did not provide pictures of the male genitalia. This incomplete description led Lindberg to misidentifications of Madeira specimens. Initially, in 1941 Lindberg reported H. angustulus for Madeira without pictures (Lindberg 1941). Later, in his work on the fauna of Cyprus (Lindberg 1948), he illustrated and compared both species morphologically. He also stated that these two species occurred in the Canary Islands and referred to his previous work ("see Lindberg, 1936"), but did not mention on what material his drawings were based or whether Horváth's material was available to him. In 1961, based on the same material of 1941 and new specimens collected by him, he mentioned that the specimens of $H$. angustulus from Madeira identified by him in 1941 were H. flavipennis (Lindberg 1961). Again, he drew what he believed to be the first illustrations of the genitalia of both species (no indication of the origin of the illustrated specimens) (Lindberg 1961: 54, fig. 4a-f). Although the drawings of 1948 and 1961 are both attributed to the same species, they show substantial differences. Only the one that Lindberg (1961) erroneously attributed to H. flavipennis resembles H. madeires in the shape of the aedeagus. Hoch \& Remane (1985) 
studied most of Lindberg's material from Madeira and identified all specimens as $H$. madeires, a new species. Together with this species they described $H$. portonoves, absent in Lindberg's material.

Hyalesthes madeires is very similar to $H$. portonoves, but the width of the anterior margin of the vertex is significantly different in the males of both species $\left(F_{1,40}=25.6, p<0.05\right)$ but not in females $\left(F_{1,24}=\right.$ $1.81, p=0.19)$. On the contrary, the opposite is true for the other characters of the body. The males are similar in all the features, $\mathrm{BL}\left(F_{1,43}=0.172, \mathrm{p}=0.68\right), \mathrm{PW}\left(F_{1,42}=2.11, p=0.15\right), \mathrm{WL}\left(F_{1,40}=0.165\right.$, $\mathrm{p}=0.68), \mathrm{MW}\left(F_{1.45}=0.00, p=0.93\right)$ and $\operatorname{ML}\left(F_{1.45}=0.018, p=0.89\right)$ (see Table 1), while the females diverge in all, $\mathrm{BL}\left(F_{1,24}=12.02, p<0.01\right)$, PW $\left(F_{1,30}=7.27, p<0.05\right), \mathrm{WL},\left(F_{1,24}=8.30, \mathrm{p}<0.01\right)$, $\operatorname{MW}\left(F_{1,30}=9.09, p<0.01\right)$, except in the length of the mesonotum $\left(F_{1,30}=2.33, p=0.13\right)$. In addition, there is intraspecific variation in the shape and width of the vertex; even within the same population, in some cases, the variation in body size can be large.

\section{Hyalesthes portonoves Remane \& Hoch, 1986}

Figs 5E, 8G-H, 12A-M

Hyalesthes portonoves Remane \& Hoch 1986: 133-135, 150-151, figs 17-20.

Hyalesthes portonoves - Hoch \& Remane 1985: 143, 145, 425, figs 65e-76e.

\section{Diagnosis}

This species differs from species of the H. angustulus group of the Canary Islands (Hoch \& Remane 1985) in the following characters (1) it has, far basally, on the left lateroventral side of the theca, a short spine, directed caudally, of variable size and thickness, absent in the Canarian species (Fig. 12I-M); (2) on the left ventral side, the long thorns are almost parallel and tips are not divergent.

\section{Material examined}

MADEIRA ISLANDS - Câmara de Lobos • 17 đో; Curral das Freiras; 610 m a.s.1.; 20 Aug. 2001; Fábio Reis leg.; on Globularia salicina; UMACI. - Funchal • 13 ô $\widehat{\jmath}, 3$ 우 o+; Casa Fogo; 200 m a.s.1.; 16 Apr. 2002; Énio B. Freitas leg.; on G. salicina; UMACI. - Machico • 2 ô ô; Pedras Brancas; 138 m a.s.l.; 14 May 2003; Énio Freitas leg.; on Suaeda vera; UMACI. - Santa Cruz • 76 §o, 8 우 ; Cristo Rei; 120 m a.s.1.; 26 Apr. 1998; Dora Pombo leg.; on G. salicina; DAPC $\bullet 2 \widehat{\jmath}, 4$ 우; same collection data as for preceding; 17 Aug. 2001; Énio B. Freitas leg.; UMACI $\bullet 5 \hat{\partial} \widehat{\partial}, 4$ $q$ q ; same collection data as for preceding; 29 Apr. 2003; DAPC • 6 §ో 6 우; Gaula; 60 m a.s.1.; 29 Apr. 2003; Énio B. Freitas leg.; on G. salicina; UMACI 6 6 + ; same collection data as for preceding; D. Aguín-Pombo leg.; UMACI •

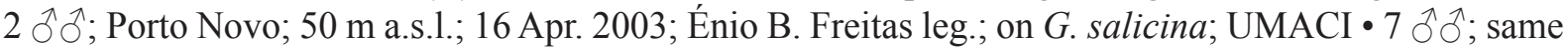

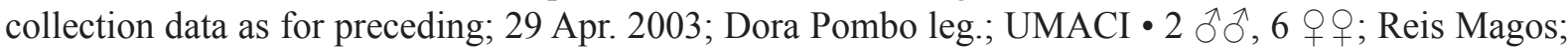
50 m a.s.1.; 29 Apr. 2003; Énio Freitas leg.; on G. salicina; UMACI • 4 q 9 ; Urbanização Garajau; 175 m a.s.1.; 17 Aug. 2001; Énio Freitas leg.; on G. salicina; UMACI.

\section{Redescription}

BODY MEASUREMENTS (mm). VW: males: $0.20-0.28,0.24 \pm 0.02(\mathrm{n}=21)$; females: $0.28-0.34,0.30 \pm 0.02$ $(\mathrm{n}=13)$. See also Table 1 .

Colouration. As in H. madeires (Fig. 3F).

Head. Vertex, frons, clypeus and medial ocellus as in H. madeires, but the vertex is usually more elongated and the margins are usually parallel (Fig. 12A-B).

Thorax. Pronotum, mesonotum, tegula, tegmina, and legs as in H. madeires (Figs 3F, 5E, 12B). 


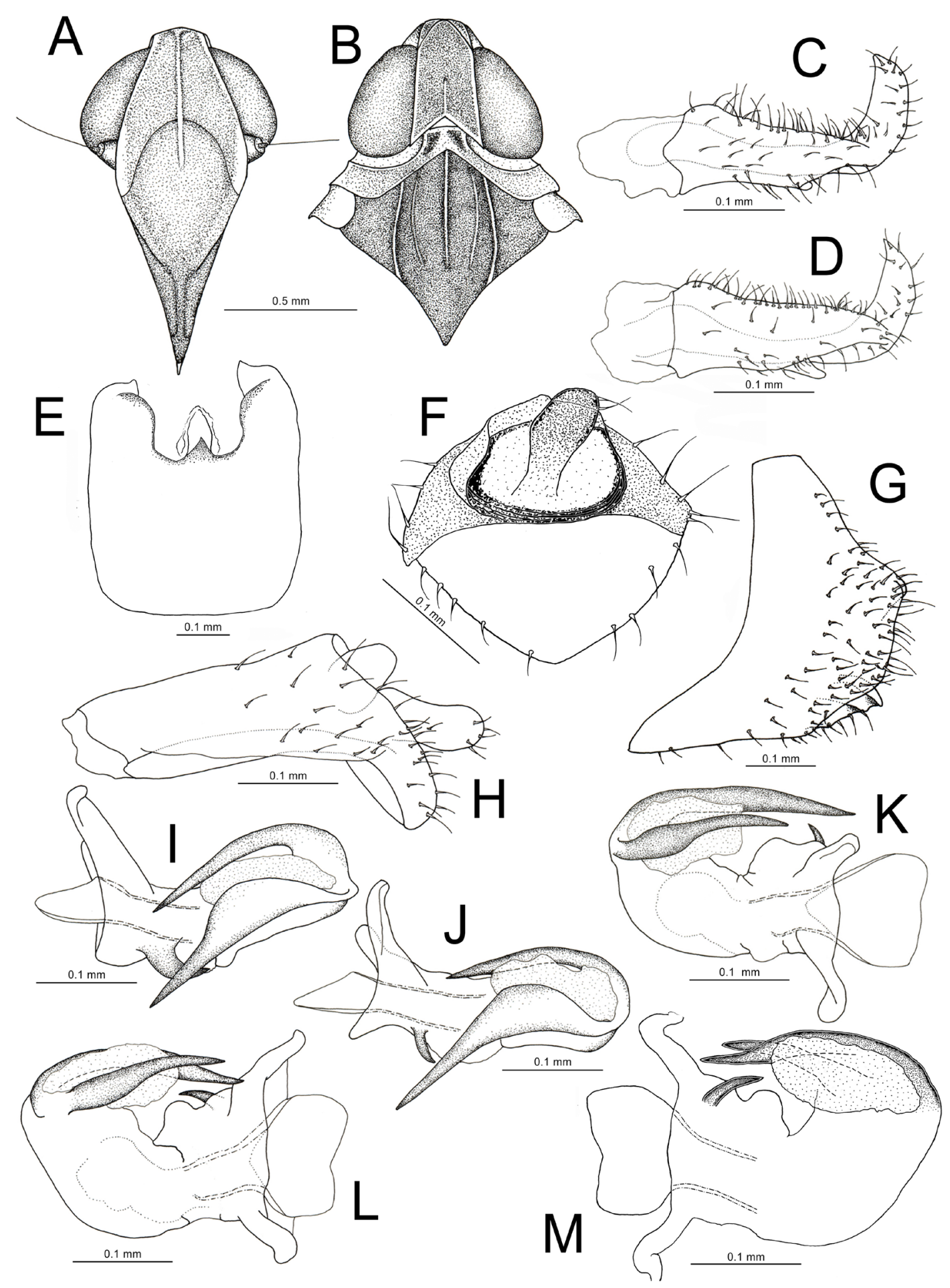

Fig. 12. Hyalesthes portonoves Remane \& Hoch, 1986. A-B. Specimen from Porto Novo, 16 Apr. 2003, on Globularia salicina Lam. C, G. Specimen from Casa Fogo, 16 Apr. 2002, on G. salicina. D, J-K. Specimens from Pedras Brancas, 14 Apr. 2002, on Suaeda vera Forssk. ex J.F.Gmel. E-F. Specimen from Gaula, 29 Apr. 2003, on G. salicina. H-I, L-M. Specimen from Porto Novo, 29 Apr. 2003, on G. salicina. A. Head (frontal view). B. Head, pronotum and scutellum (dorsal view). C-D. Left paramere. E. Pygofer (ventral view). F. Anal tube (caudal view). G. Pygofer (left lateral view). H. Anal tube (left lateral view). I-M. Aedeagus (I-J, left lateral view; K-L, dorsal view; M, ventral view). 
Male genitalia (see also Remane \& Hoch 1986). Pygofer, anal tube, anal styles and parameres as in H. madeires (Fig. 12C-H). Body length, position, and curvature of the ventral spine, and the dorsocaudal thorns of the aedeagus as in $H$. madeires, but the thorns are almost parallel or divergent distally and sometimes the dorsal thorn medially touches the ventral spine (Fig. 12I-J). The thorns extend along $4 / 5$ of the aedeagus but without overlapping distally. The dorsal thorn is oblique and straight, and is basally directed towards the ventral spine (Fig. 12I-J). The ventral thorn is thicker and longer than the dorsal; it is approximately 3 times as wide and thick in the middle part than it is at the base, and sometimes the ventral margin is slightly arched in the middle part; in dorsal and ventral view they cross (Fig. 12K-M).

Female genitalia. As shown in Fig. 8G-H.

\section{Distribution and ecology}

Endemic to the island of Madeira. It is present from low to medium altitudes within the xerophytic shrub communities of the south of the island both in the coastal regions and in the gorges. Adults occur from April to August on Globularia salicina and Suaeda vera, but they have also been collected from Echium and Euphorbia species (Hoch \& Remane 1985; Remane \& Hoch 1986). It seems to prefer more exposed areas than $H$. madeires.

\section{Remarks}

There are intraspecific differences in the male genitalia. The ventral spine can vary in length, thickness, and curvature (Fig. 12I-J).

Genus Pentastiridius Kirschbaum, 1868

Pentastiridius (Pentastiridius) leporinus (Linnaeus, 1761)

Fig. $13 \mathrm{~A}-\mathrm{G}$

Cicada leporina Linnaeus, 1761: 242.

Cixius latifrons Walker, 1851: 283-284 (for discussion of other synonyms see Webb et al. 2013).

\section{Diagnosis}

It differs from other European species of the genus in the following characters: (1) the apex of the velum ends in two processes, a ventral tongue-shaped expansion and, exceeding it, a thin, spine-like extension curved downward; (2) on the right, laterobasal to the base of the aedeagus, is a long, thin spine that extends around the theca and almost embraces it; this thorn is slender and the distal third is bent at a right angle.

\section{Material examined}

MADEIRA ISLANDS - Ponta do Sol • 3 $\widehat{\jmath}$; ; Lugar de Baixo lagoon; 8 m a.s.1.; 30 May 2004;

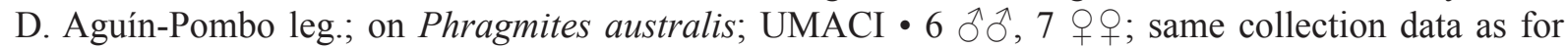
preceding; 15 Jun. 2017; DAPC.

\section{Redescription}

BODY MEASUREMENTS (mm). BL: males 6.56-7.25 $(\mathrm{n}=8)$; females 8.67-9.38 $(\mathrm{n}=6)$.

Colouration. Vertex with a medial rectangular blackish spot; lateral sides of the vertex, pronotum and the areolar and frontal carinal areas, pale yellow; frons, clypeus, gena, and lora black in males, golden brown in females. Mesonotum and femora black in males and lighter in females. Female tegmina milky white, semitransparent; veins and stigmas of pale golden colour, in males they are darker. 
HeAd. Vertex almost as long as wide in the posterior margin (Fig. 13A). Epistomal suture pronounced in a wave form.

THorax. Mesonotum with five distinctly ridged carinae; the costal carinae are slightly divergent and reach almost the posterior margin of the mesonotum, being shorter than the medial and intercostal carinae; these two end up subapically at the caudal margin of the mesonotum; the intercostal carinae are shaped as a pair of parentheses and at the base are shorter than the medial and costal carinae (Fig. 13A).
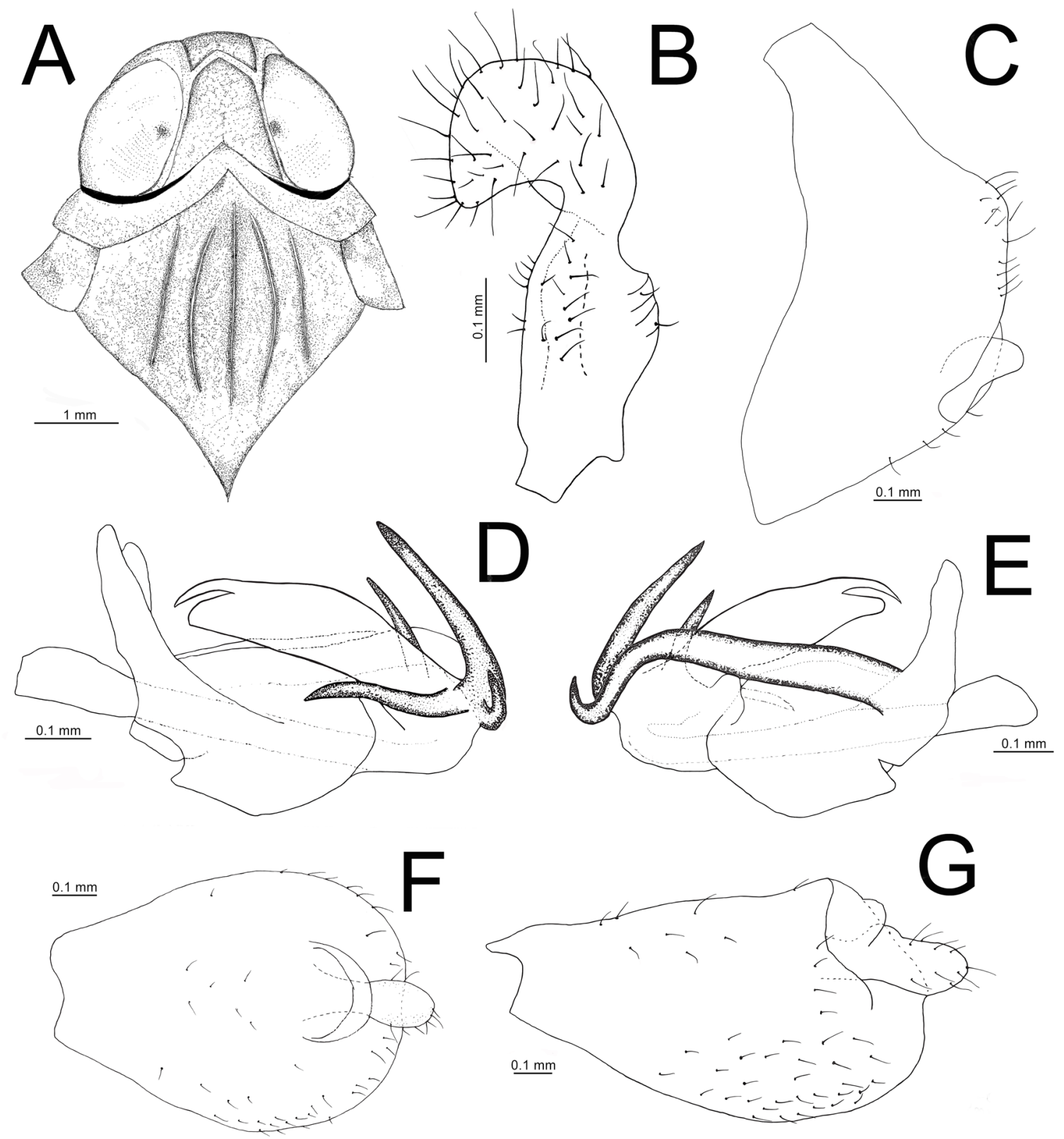

Fig. 13. Pentastiridus leporinus (Linnaeus, 1761). Specimens from Lugar de Baixo lagoon, 30 May 2004, on Phragmites australis Trin. ex Steud. A. Head, pronotum, and scutellum (dorsal view). B. Left paramere. C. Pygofer (left lateral view). D-E. Aedeagus (left and right lateral view). F-G. Anal tube (dorsal and left lateral view). 
Male genitalia (see also Holzinger et al. 2003). Pygofer lobes concave distally (Fig. 13C). The anal tube is oblong dorsally and distally blunt; at the base it is 2 times shorter than caudallly (Fig. 13F); lateroventral margins widely concave (Fig. 13G). Parameres 2.5 times as long as wide in the widest part; caudally there is a large rounded subtriangular area that narrows basally towards the outer margin; inner lateral margin slightly concave and outer margin straight (Fig. 13B). The aedeagus base forms dorsolaterally an almost flat pentagonal plate; from the middle to the distal end of the plate rises dorsolaterally a caudally directed process. Velum is arch-shaped and narrows towards the apex; distally and dorsoventrally, the apex ends in a tongue-shaped process, and dorsally, exceeding this, there is a thin spine that curves down. On the right, laterobasal at the base of the aedeagus, there is a long and thin spine that extends parallel almost embracing it distally; this thorn narrows towards the apex and the distal third bends upward in the form of a sickle (Fig. 13E). Dorsally, at the base of the velum, there is a small spine-like process and from here three movable spines are raised, one long and thick and two small and thin; the longest extends parallel to the dorsal margin of the flagellum and reaches approximately half of its length; the shortest spine is almost parallel to the base of the flagellum and bends slightly medially downwards; the last spine is oblique to the velum (Fig. 13D).

Female genitalia. Not described.

\section{Distribution and habitat}

The Palearctic region, except in the northern parts. In Madeira, this species is found in Phragmites australis Trin. ex Steud. in the only tide lagoon of the island, which is located on the southern coast.

\section{Remarks}

The curvature of the long lateroventral spine of the aedeagus is variable at its distal end as is shown in Wagner (1970: fig. 3c).

\section{Key of Madeiran Cixiidae based on males}

1. Mesonotum with 3 carinae (Figs 4B, 7B, 9B, 10B)

- Mesonotum with 5 carinae (Figs 11B, 12B, 13A)

2. Body length $<5 \mathrm{~mm}$; vertex tongue-shaped, posterior margin quadrangular (Fig. 10B); medial carina of frons smooth, reaching the posterior margin of the postclypeus (Fig. 10A); apical margin of tegmina oval with tubercles on the apical margin between the veins (Figs 3E, 10I); first metatarsus with 6 spines distally

Tachycixius chaoensis (China, 1938)

- Body length > $5 \mathrm{~mm}$; shape of vertex different, posterior margin concave (Figs 4B, 7B, 9B-D); medial carina of frons distinctively ridged, extending along the frons and the clypeus (Figs 4A, 7A, 9A); apical margin of the tegmina rounded, usually without tubercles on the apical margin between veins, if present they are few (Fig. 5A-C); first metatarsus with 8 spines distally 3

3. Body length 5.06-5.67 mm; light brown body (Fig. 3A-B); anterior margin of the vertex rounded or slightly acute, slightly concave at the back (Fig. 9B-D); mesonotum light brown; tegmina light golden brown, almost 2 times as long as wide, with small brown setiferous tubercles along the longitudinal veins

C. madeirensis China, 1938

- Body length $>5.90 \mathrm{~mm}$; light blackish to dark brown body; anterior margin of the vertex acute and posterior margin distinctively concave (Fig. 4B, 7B); mesonotum black; tegmina whitish, 2.75 times as long as wide, with large black setiferous points along the longitudinal veins 
4. Body length $>7.20 \mathrm{~mm}$. Vertex slightly acute at the anterior margin and concave at posterior margin (Fig. 7B); ventral margin of the aedeagus with a finger-shaped expansion; the largest lateral thorn curves distally forming an angle of $90^{\circ}$; vellum gibbous, without dorsal denticle and the ventral margin distinctively curved distally (Fig. $7 \mathrm{~K}-\mathrm{N}$ )

C. verticalis Noualhier, 1897

- Body length $<7.20 \mathrm{~mm}$. Vertex distinctly acute at the anterior margin and tongue-shaped at the posterior margin (Fig. 4B); ventral margin of the aedeagus with a wave-shaped expansion; the larger lateral thorn is curved and does not form a $90^{\circ}$ angle distally; vellum subtrapezoid, with a small dorsal denticle and the ventral margin almost straight distally (Fig. $4 \mathrm{~K}-\mathrm{N})$....C. wollastoni sp. nov.

5. Body length $>5 \mathrm{~mm}$; first metatarsus with more than 10 spines. Aedeagus with a long, hook-shaped thorn along the right lateral side and 3 smaller thorns distally on the left side of the aedeagus, two of them much longer (Fig. 13D-E)

Pentastiridus leporinus (Linnaeus, 1761)

- Body length $<5 \mathrm{~mm}$; first metatarsus with less than 10 spines. Aedeagus with two long, thin thorns on the left lateral side (Figs 11I-M, 12I-M) ......

6. Vertex often short, lateral margins usually converging anteriorly (Fig. 11B); in lateral view, dorsal thorn of aedeagus wider and longer than the ventral thorn, both converging distally (Fig. 11I-M) ...

H. madeires Remane \& Hoch, 1986

- Vertex often long, lateral margins usually parallel (Fig. 12B); in lateral view, dorsal thorn of aedeagus more slender and shorter than the ventral thorn, both distally parallel or divergent (Fig. 12I-M) ....

H. portonoves Remane \& Hoch, 1986

\section{Discussion}

The Cixius species of Madeira are morphologically very similar but, in terms of genital structures, they form a different group from those of the Azores and the Canary Islands. The Madeiran Cixius species are separated from the species of the Cixius insularis and the Cixius azoricus groups of the Azores in the position, number and size of the thorns and the shape of the velum. The species of the Azores, instead of two, have three large thorns, one on the left side and two on the right side of the aedeagus, of equal (C. insularis group) or unequal size (C. azoricus group) (Remane \& Asche 1979; Hoch 1991). The most similar species to those of Madeira is C. palmensis Lindberg, 1960 of the Canary Islands, but the size and curvature of the spines of the aedeagus are different and the velum expands further at the base, while the apex is sharp, not rounded (Hoch \& Asche 1993).

The assignment of the species of Madeira to one of the described subgenera of Cixius is problematic. Wagner (1939) recognized 10 subgenera of Cixius, based on the form of aedeagus. Another Mediterranean subgenus was described by Ribaut (1960), and some subgenera were synonymised by Holzinger et al. (2003). Lindberg (1954: 4) suggested that $C$. verticalis (probably actually C. madeirensis) should be placed close to the subgenus Ceratocixius Wagner, 1939. The Madeira species have two movable thorns, as in the species of the subgenus Ceratocixius. However, the thorns are distinctively unequal and the bending direction is different; the ventral process of the aedeagus is not a pronounced crest but a smaller finger-shaped process, and the flagellum has a hump-shaped expansion which is absent in Ceratocixius spp. Lindberg (1960: 15) also suggested that $C$. palmensis is more closely related to the species of the subgenera Paracixius Wagner, 1939 and Ceratocixius. The phylogenetic significance of the differences in these aedeagal structures remains to be clarified; thus, a reliable assignment to the weakly defined subgenera of Cixius can only be made after a phylogenetic analysis of the genus.

The configuration of the male genitalia in Tachycixius chaoensis is also different from that of the species of the Canary Islands. The phylogeny of the genus Tachycixius is unknown. Presently, the genus comprises 26 species, including $T$. chaoensis, grouped according with the shape of genital structures, 
FREITAS É. \& AGUÍN-POMBO D., Taxonomy of the Cixiidae from the Madeira archipelago

in five species-groups (Holzinger 2000; Holzinger et al. 2002). The T. canariensis group comprises all the species of the Canary Islands. Tachycixius chaoensis differs from the species of this group in the presence of a small movable spine on each side of the aedeagus instead of two large thorns on the right side. In addition, the apex of the flagellum is bifid and not blunt, and the theca has ventrally a rigid spine, absent in the canariensis group. Like T. chaoensis, Cixius (Ceratocixius) suaedicola Remane \& Holzinger, 1998, from southwest Morocco, is associated with the halophyte Suaeda Forssk. ex J.F.Gmel. However, the aedeagus configuration is different. In T. chaoensis, the ventral margin of the aedeagus does not have a large keel, the movable spines are much smaller, the apex of the vellum ends in two instead of one spine and has no arch form but a hump. The conformation of the thorns in T. chaoensis is more like species of the pilosus group (i.e., T. arzonei Holzinger, 2000 and T. remanei D'Urso, 1999). It shares with these a ventral rigid spine and a movable spine on each side of the aedeagus. But the movable spines in $T$. chaoensis are of similar size, much smaller and strongly curved upwards. The length of the forewings and the size of the body of males and females of T. chaoensis is also smaller than the species of the T. pilosus group (see Holzinger 2000: 1271). Females differ also. In T. pilosus, tergite IX rises perpendicular to the body axis, and the ovipositor curves dorsally, a configuration considered apomorphic in some cixiids (see Holzinger et al. 2002). In T. chaoensis tergite IX narrows towards the anal segment and the ovipositor curves dorsally, reaching the genital segment, a pattern considered plesiomorphic. The phylogenetic relationships between the species of the different groups are unknown and the monophyly of the genus questioned (Holzinger et al. 2002).

The phylogenetic analysis of the species of the genus Hyalesthes conducted by Hoch \& Remane (1985) includes the species of Hyalesthes of Madeira in the monophyletic group of H. angustulus. In addition to $H$. angustulus, present on the Canary Islands and in North Africa, this group contains two endemic species of the Canary Islands: H. flavipennis Horváth, 1909 and H. teno Remane \& Hoch, 1986. The apomorphies of the $H$. angustulus group are three: the folded section of the aedeagus is shortened and moves to the left side, the distal basal thorn (at least partially) is integrated into the membranous area of the distal part of the aedeagus, and the anteclypeus and postclypeus are smooth, without medial decay (ibid.). Madeira species share with the angustulus group two large thorns directed caudally on the left side of the aedeagus, of which at least one bends obliquely to the aedeagus base. But it differs from them in the presence of a small medioventral spine near the base of the aedeagus and the size and curvature of the thorns also differ.

The Azores, Madeira, and the Canary Islands are the only Macaronesian archipelagoes with endemic species of Cixiidae. Some lineages of the genus Cixius, Tachycixius and Hyalesthes gave rise to endemic species in the Canary Islands and Madeira, while in the Azores all endemic species belong to the genus Cixius. Some Tachycixius and Cixius have evolutionarily adapted to life in caves (Remane \& Hoch 1988; Hoch 1991; Hoch \& Asche 1993). Of the 10 troglobitic species known, two (Cixius spp.) occur in the Azores and eight (Cixius, 6 spp; Tachycixus, 2 spp.) in the Canary Islands. In Madeira, the cave fauna of the Cavalum lavatubes (Madeira Island) was studied over a year by Élvio Nunes and Aguín-Pombo, but no troglobitic species were found. Despite this, the number of endemic species of the island of Madeira is remarkably large. It is the same as Tenerife (Oromí et al. 2004), an island which is almost three times larger, twice as high and ecologically more diverse in habitats (Fernández-Palacios et al. 2004). In oceanic archipelagoes such as Madeira, which have never been joined to the continent, the number of islands, the area, the age, the distance to the mainland and the habitat diversity play key roles in colonization and species differentiation. Oceanic islands are rich in biodiversity, particularly concerning endemic species, but also have much higher extinction rates (Frankham 1997, 1998). Endemic species with restricted distribution, such as T. chaoensis, and possibly also $C$. wollastoni sp. nov., deserve special attention during the designation and management of protected areas. 


\section{Acknowledgments}

We are indebted to Élvio Nunes and Iola Martins for collecting specimens of $C$. wollastoni and Élvio Nunes also for looking for cixiids in the Cavalum laval tubes of Madeira Island. We also thank Mick Webb (Natural History Museum, London) for providing information on T. chaoensis, his help with the designation of a lectotype and for providing a photo of this lectotype by Ken Merrifield. Thierry Bourgoin and Laurent Fauvre of the Muséum national d'histoire naturelle (Paris) are thanked for the loan of type material and for curation assistance, respectively. We are very much indebted to Werner Holzinger (Germany) for critical comments on the manuscript and to him and Dr A.F. Emeljanov (Russian Academy of Sciences) for important taxonomic information. This work was partially financed by an EU grant (COLPARSYST) to the second author, and by the 2002-2006 Environmental monitoring programs of the Solid Waste Treatment Station (ETRS) of Meia Serra (Madeira, Portugal). The authors declare that no competing interests exist.

\section{References}

Adamson A.M. 1939. Review of the fauna of the Marquesas Islands and discussion of its origin. Bishop Museum Bulletin 159: 1-93. https://doi.org/10.5281/zenodo.805085

Aguín-Pombo D. \& Freitas C. 2008. An annotated checklist of the Cicadomorpha and Fulgoromorpha (Hemiptera) of the Madeira and Salvages archipelagos. Zootaxa 1762 (1): 1-28. https://doi.org/10.11646/zootaxa.1762.1.1

Aguín-Pombo D. \& Pinheiro de Carvalho M.A.A. 2009. Madeira Archipelago. In: Gillespie R. \& Clague D. (eds) Encyclopedia of Islands: 582-585. University of California Press, Oakland, CA.

Asche M. 1997. Review of the systematics of Hawaiian planthoppers (Hemiptera: Fulgoroidea). Pacific Science 51 (4): 366-376.

Attié M., Bourgoin T. \& Bonfils J. 2002. The Cixiidae (Hemiptera: Fulgoromorpha) of the Mascarenes islands and Madagascar. Endemism and description of new taxa from Réunion with notes on their host plants. European Journal of Entomology 99: 543-555. https://doi.org/10.14411/eje.2002.071

Borges P.A.V., Abreu C., Aguiar A.M.F., Carvalho P., Jardim R., Melo I., Oliveira P., Sérgio C., Serrano A.R.M. \& Vieira P. (eds). 2008. A List of the Terrestrial Fungi, Flora and Fauna of Madeira and Selvagens Archipelagos. Direcção Regional do Ambiente da Madeira and Universidade dos Açores, Funchal and Angra do Heroísmo, Portugal.

Carvalho J.A., Fernandes F. \& Santos-Guerra A. 2013. The vascular flora of Porto Santo: a catalogue of its islets. Boletim do Museu Municipal do Funchal 63 (335): 5-20.

China W.E. 1938. Die Arthropodenfauna von Madeira nach den Ergebnissen der Reise von Prof. Dr. O. Lundblad Juli-August 1935. III Terrestrial Hemiptera. Arkiv för Zoologi 30A (2): 1-69.

Cropper T. 2013. The weather and climate of Macaronesia: past, present and future. Weather 68 (11): 300-307. https://doi.org/10.1002/wea.2155

Faust-Lichtenberger U. 1988. Beitrag zur Geographie der Mittelatlantischen Insel Porto Santo, Madeira Archipel. Schriften des Naturwissenschaftlichen Vereins für Schleswig-Holstein 58: 103-114.

Fernández-Palacios J.M., Arévalo J.R., Delgado J.D. \& Otto R. 2004. Canarias: Ecología, Medio Ambiente y Desarrollo. Gobierno de Canarias, Consejería de Política Territorial y Medio Ambiente, G.Z. Printek, S.A., Vizcaya.

Fontinha S. \& Carvalho J.A. 1995. Evaluation of the vascular flora of Madeira's extreme east. Boletim do Museu Municipal do Funchal, Suplemento 4: 263-275. 
Frankham R. 1997. Do island populations have less genetic variation than mainland populations? Heredity 78: 311-327. https://doi.org/10.1038/hdy.1997.46

Frankham R. 1998. Inbreeding and extinction: island populations. Conservation Biology 12 (3): 665675. https://doi.org/10.1111/j.1523-1739.1998.96456.x

Hampshire J.R. 1984. A study of the vegetation of the Ponta de São Lourenço in Madeira, Ilhéu Chão and Deserta Grande. Boletim do Museu Municipal do Funchal 36 (164): 207-226.

Hoch H. 1991. Cave-dwelling Cixiidae (Homoptera, Fulgoroidea) from the Azores. Bocagiana 149: $1-9$.

Hoch H. \& Asche M. 1993. Evolution and speciation of cave-dwelling Fulgoroidea in the Canary Islands (Homoptera: Cixiidae and Meenoplidae). Zoological Journal of the Linnean Society 109: 53101. https://doi.org/10.1111/j.1096-3642.1993.tb01259.x

Hoch H. \& Remane R. 1985. Evolution und Speziation der Zikaden-Gattung Hyalesthes Sign., 1865 (Homoptera Auchenorrhyncha Fulgoroidea Cixiidae). Marburger Entomologische Publikationen 2 (2): $1-427$.

Holzinger W.E. 2000. Tachycixius arzonei sp. n., a new planthopper species from Italy (Insecta: Hemiptera: Fulgoromorpha: Cixiidae). Linzer biologische Beiträge 32 (2): 1269-1274.

Holzinger W.E., Emeljanov A.F. \& Kammerlander I. 2002. The family Cixiidae Spinola 1839 (Hemiptera, Fulgoromorpha) - a review. Denisia 4: 113-138.

Holzinger W.E., Kammerlander I. \& Nickel H. 2003. The Auchenorrhyncha of Central Europe. Die Zikaden Mitteleuropas. Fulgoromorpha, Cicadomorpha excl. Cicadellidae. Brill, Netherlands.

Holzinger W.E., Löcker H. \& Löcker B. 2008. Fulgoromorpha of Seychelles: a preliminary checklist. Bulletin of Insectology 61 (1): 121-122.

Horváth G. 1909. Hémiptères recueillis par M. Th. Becker aux Îles Canaries. Annales Musei historiconaturalis hungarici 7: 290-301.

IUCN. 1999. The Laurisilva of Madeira (Portugal). In: IUCN (ed.) World Heritage Committee. IUC. Evaluation of Nominations of Natural and Mixed Properties to the World Heritage List. Report to the Twenty-third Ordinary Session of the World Heritage Committee: 93-97. Marrakesh, Morocco.

Jardim R., Fontinha S. \& Fernandes F.M. 1998. Pico Branco: a peculiar floristic site on Porto Santo Island. Boletin do Museu Municipal do Funchal 50 (285): 43-57.

Lindberg H. 1941. Die Hemipteren der Azorischen Inseln. Nebst Anhang: Zur Kenntis der Hemipterenfauna von Madeira. Commentationes Biologicae 8 (8): 1-32.

Lindberg H. 1948. On the insect fauna of Cyprus. Results of the expedition of 1939 by Harald, Hakan and P.H. Lindberg, I. Introduction, II. Heteroptera und Homoptera Cicadina der Insel Zypern. Commentationes Biologicae 10 (7): 1-175.

Lindberg H. 1954. Hemiptera Insularum Canariensium: Systematik, Ökologie und Verbreitung der Kanarischen Heteropteren und Cicadiden. Commentationes Biologicae 14 (1): 1-304.

Lindberg H. 1960. Supplement Hemipterorum Insularum Canariensium. Commentationes Biologicae 22 (6): 5-20.

Lindberg H. 1961. Hemiptera Insularum Madeirensium. Commentationes Biologicae 24 (1): 1-82.

Linnaeus C. 1761. Fauna Svecica Sistens Animalia Sveciae Regni: Mammalia, Aves, Amphibia, Pisces, Insecta, Vermes. Distributa per classes \& ordines, genera \& species, cum differentiis specierum, 
synonymis auctorum, nominibus incolarum, locis natalium, descriptionibus insectorum. Editio altera, auctior. Stockholm. https://doi.org/10.5962/bhl.title.46380

Martín J.L., Arechavaleta M., Borges P.A.V. \& Faria B. (eds). 2008. Top 100. Las 100 Especies Amenazadas Prioritarias de Gestión en la Región Europea Biogeográfica de la Macaronesia. Consejería de Medio Ambiente y Ordenación Territorial, Gobierno de Canarias.

Médail E. \& Quézel P. 1999. Biodiversity hotspots in the Mediterranean Basin: setting global conservation priorities. Conservation Biology 13 (6): 1510-1513. https://doi.org/10.1046/j.1523-1739.1999.98467.x

Myers N., Mittermeier R.A., Mittermeier C.G., da Fonseca G.A.B. \& Kent J. 2000. Biodiversity hotspots for conservation priorities. Nature 403: 853-858. https://doi.org/10.1038/35002501

Neves H.C., Silva I. \& Palmeira C. 1992. Contributions to the knowledge of the flora of Desertas Islands. Bocagiana 163: 1-21.

Neves H.C., Valente A.V., Faria B.F., Silva I., Marques J.C., Gouveia N.A. \& Silva P.G. 1996. Laurissilva da Madeira - Caracterização Quantitativa e Qualitativa. Parque Natural da Madeira, Grafimadeira S.A., Funchal.

Nouhalier M. 1897. Hémiptères recueillis par M.A. Fauvel à Madere en mai et en juin 1896. Revue d'Entomologie 16: 76-80.

Oromí P. 2004. Biospeleology in Macaronesia. AMC Bulletin 19/SMES Boletín 7: 98 -104.

Press J.R. \& Short M.J. 1994. Flora of Madeira. HMSO, London.

Remane R. \& Asche M. 1979. Evolution und Speziation der Gattung Cixius Latreille, 1804 (Homoptera, Auchenorrhyncha, Fulgoromorpha, Cixiidae) auf den Azorischen Inseln. Marburger Entomologische Publikationen 1 (2): 1-264.

Remane R. \& Hoch H. 1986. Sechs neue Arten der Gattung Hyalesthes Signoret, 1865 (Homoptera Fulgoroidea Cixiidae) von den Mittelatlantischen Inseln und aus dem Irak. Marburger Entomologische Publikationen 2 (3): 123-151.

Remane R. \& Hoch H. 1988. Cave-dwelling Fulgoroidea (Homoptera: Auchenorrhyncha) from the Canary Islands. Journal of Natural History 22: 403-412. https://doi.org/10.1080/00222938800770291

Ribaut H. 1960. Deux cixiides nouveaux des Pyrénées-Orientales (Homoptera Cixiidae). Bulletin de la Société d'Histoire naturelle de Toulouse 95: 197-201.

Sjögren E. 1972. Vascular plant communities of Madeira. Boletim do Museu Municipal do Funchal 26 (114): 45-125.

Søndergaard P. 1995. Introduction of exotic woody plant species in a degraded island ecosystem (Porto Santo in the Madeira archipelago). Bocconea 5: 409-416.

Vanderpoorten A., Rumsey F.J. \& Carine M.A. 2007. Does Macaronesia exist? Conflicting signal in the bryophyte and pteridophyte floras. American Journal of Botany 94 (4): 625-639.

https://doi.org/10.3732/ajb.94.4.625

Wagner W. 1939. Die Zikaden des Mainzer Beckens, zugleich eine Revision der Kirschbaumschen Arten aus der Umgebung von Wiesbaden. Jahrbuch des Nassauer Vereins für Naturkunde 86: 77-212.

Wagner W. 1970. Oliarus beieri, eine neue Cixiidae aus den Alpen. Annalen des Naturhistorischen Museums in Wien 74: 281-284.

Walker F. 1851. List of the Specimens of Homopterous Insects in the Collection of the British Museum. Part 2: 261-636. Trustees of the British Museum, London. https://doi.org/10.5962/bhl.title.9063 
Webb M.D., Ramsay A.J. \& Lemaítre V.A. 2013. Revealing the identity of some early described European Cixiidae (Hemiptera: Auchenorrhyncha) - a case of 'forensic' taxonomy; two new combinations and a name change for Reptalus panzeri in Britain. Acta Musei Moraviae, Scientiae biologicae 98 (2): 57-95.

Wilson M. 2009. A checklist of Fiji Auchenorrhyncha (Hemiptera). Fiji Arthropods XII. Bishop Museum Occasional Papers 102: 33-48.

Manuscript received: 4 April 2020

Manuscript accepted: 10 December 2020

Published on: 5 April 2021

Topic editor: Rudy Jocqué

Desk editor: Pepe Fernández

Printed versions of all papers are also deposited in the libraries of the institutes that are members of the EJT consortium: Muséum national d'histoire naturelle, Paris, France; Meise Botanic Garden, Belgium; Royal Museum for Central Africa, Tervuren, Belgium; Royal Belgian Institute of Natural Sciences, Brussels, Belgium; Natural History Museum of Denmark, Copenhagen, Denmark; Naturalis Biodiversity Center, Leiden, the Netherlands; Museo Nacional de Ciencias Naturales-CSIC, Madrid, Spain; Real Jardín Botánico de Madrid CSIC, Spain; Zoological Research Museum Alexander Koenig, Bonn, Germany; National Museum, Prague, Czech Republic. 